\title{
Field Evaluation of Reduced Rate Brassicaceae Seed Meal Amendment and Rootstock Genotype on the Microbiome and Control of Apple Replant Disease
}

\author{
Likun Wang ${ }^{1}$ and Mark Mazzola2,† \\ ${ }^{1}$ Department of Plant Pathology, Washington State University, Pullman, WA 99164 \\ ${ }^{2}$ U.S. Department of Agriculture-Agricultural Research Service Tree Fruit Research Laboratory, Wenatchee, WA 98801 \\ Accepted for publication 18 March 2019.
}

ABSTRACT

\begin{abstract}
An orchard field trial was conducted to assess the utility of reduced rate Brassicaceae seed meal (SM) amendment in concert with specific rootstock genotypes for effective control of apple replant disease. Three amendment rates of a 1:1 formulation of Brassica juncea-Sinapis alba SM were compared with preplant 1,3-dichloropropene/chloropicrin soil fumigation for disease control efficacy. When applied at the highest rate $\left(6.6 \mathrm{tha}^{-1}\right)$ in the spring of planting, SM caused significant phytotoxicity and tree mortality, which was higher for Gala/M.26 than for Gala/G.41 but was not observed at SM application rates of 2.2 or $4.4 \mathrm{tha}^{-1}$. SM treatment resulted in growth and yield increases of Gala/M.26 and Gala/G.41 trees in a manner similar to the fumigation treatment and significantly greater than the no treatment control. Tree growth in soils treated with SM at $4.4 \mathrm{tha}^{-1}$ was similar or superior to that obtained with $\mathrm{SM}$ at $6.6 \mathrm{tha}^{-1}$ and superior to that attained at an SM application rate of $2.2 \mathrm{t} \mathrm{ha}^{-1}$. Soil fumigation and all SM treatments reduced Pratylenchus penetrans root infestation relative to the control treatment at the end of the initial growing season. Lesion
\end{abstract}

Repeatedly planting the same or closely related plant species in field systems is a primary factor leading to reduced crop productivity in agroecosystems. In annual cropping systems, buildup of pathogen populations and rapid spread of diseases caused by continuous monoculture can result in significant economic loss (Shipton 1977). In perennial cropping systems, orchards that previously produced profitable fruit yields may not support satisfactory growth of the same or closely related species of replanted trees, even when recommended cultural practices have been followed (Mai and Abawi 1981). This phenomenon is typically referred to as replant disease or replant disorder. Replant disease has been widely documented around the world in all major fruit-growing regions (Traquair 1984), and chronic root health issues are commonly cited as the cause. An assemblage of pathogens has been documented as the primary causal agents of the disease and includes but is not limited to species of the genera Ilyonectria, Phytophthora, Pythium, and Rhizoctonia along with the endoparasitic nematode Pratylenchus penetrans (Jaffee et al. 1982a, b; Mazzola 1998; Tewoldemedhin et al. 2011).

Management of apple replant disease in commercial orchards is primarily based on preplant soil fumigation and the use of tolerant rootstock genotypes (Braun et al. 2010; Covey et al. 1979; Zhu et al.

${ }^{\dagger}$ Corresponding author: M. Mazzola; mark.mazzola@ars.usda.gov

Funding: This work was supported in part through funding from the U.S. Department of Agriculture National Institute of Food and Agriculture under awards 2012-51102-20294 and 2016-51102-25815.

The author(s) declare no conflict of interest.

This article is in the public domain and not copyrightable. It may be freely reprinted with customary crediting of the source. The American Phytopathological Society, 2019. nematode root densities in the fumigation treatment, but not SM treatments, rapidly recovered and were indistinguishable from the control at the end of the second growing season. Soil fumigation and all SM treatments significantly suppressed Pythium spp. root infection relative to the control. Trees grafted to rootstock G.41 possessed lower P. penetrans root densities relative to trees grafted to rootstock M.26. One year after planting, composition of microbial communities from SM-amended soils was distinct from those detected in control and fumigated soils, and the differences were amplified with increasing SM application rate. Specific fungal and bacterial phyla associated with suppression of plant pathogens were more abundant in SM-treated soil relative to the control, and they were similar in abundance in 4.4- and 6.6-t ha ${ }^{-1} \mathrm{SM}$ treatments. Findings from this study demonstrated that use of the appropriate apple rootstock genotype will allow for effective replant disease control at SM application rates significantly less than that utilized previously $\left(6.6 \mathrm{t} \mathrm{ha}^{-1}\right)$.

Keyword: pest management
2014). The latter has demonstrated large site to site variation in efficacy, and soil fumigation has been reported to yield a short-term (1-year) growth response (Auvil et al. 2011). Studies demonstrated that the rhizosphere microbiome, including elements of the replant disease causal pathogen population, reverted rapidly in fumigated soil on planting to apple, and its composition was indistinguishable from the untreated control by the end of two growing seasons (Mazzola et al. 2015). Considering the environmental concerns, the relative efficacy of available chemical fumigants, and the increasing demand for organic apple products, there has been renewed interest in the development of nonfumigant soilborne pest control methods. A potential alternative treatment is the preplant application of Brassicaceae seed meal (SM) as a soil amendment, which has demonstrated capacity to provide effective and long-term suppression of some soilborne pathogens, nematodes, and weeds (Cohen and Mazzola 2006; Cohen et al. 2005; Mazzola et al. 2015; Weerakoon et al. 2012).

Brassicaceae plant residues have been used widely as a means to enhance soil health and provide control of soilborne plant diseases (Mazzola and Manici 2012). The materials have been used with the belief that efficacy is dependent on the generation of various glucosinolate hydrolysis products, including isothiocyanates (ITCs), and thus, the approach has been termed biofumigation (Kirkegaard et al. 1993). Brassicaceae SM amendments provide disease control through various mechanisms, both biological and chemical, which vary with both the SM plant source and the target pathogen (Cohen and Mazzola 2006; Mazzola et al. 2007). Brassica juncea SM mixed with Biolan peat B3 applied to cabbage seeds effectively controlled Rhizoctonia damping off without negatively affecting germination of the treated seeds (Chung et al. 2002). Application of SM derived from a single species provided limited pest suppression of replant disease in orchard field trials (Mazzola 
and Brown 2010). However, in trials conducted in organic orchard systems, the use of a specific composite B. juncea-Sinapis alba SM formulation provided disease control and plant growth responses equivalent or superior to that attained through preplant fumigation with 1,3-dichlropropene (1,3-D)/chloropicrin (Mazzola et al. 2015).

The glucosinolate hydrolysis product allyl isothiocyanate (AITC) is generated on application of B. juncea SM to moist soil. AITC exhibits suppression of multiple pathogens that incite apple replant disease in a manner that varies temporally. Peak emission of AITC is dependent on several factors, including SM particle size (Mazzola and Zhao 2010), soil temperature, and soil water potential (Wang and Mazzola 2019a). Direct pesticidal activity of SM generated volatiles functions during the period immediately (24 to $48 \mathrm{~h}$ ) after soil incorporation of the SM, the phase during which detectable levels of AITC are generated. In contrast, effective suppression of Rhizoctonia root rot (Mazzola et al. 2001) and $P$. penetrans root infection (Cohen et al. 2005) were observed in response to $B$. napus $\mathrm{SM}$ soil amendment, although no bioactive glucosinolate hydrolysis products were generated. Results from studies have demonstrated that the resident soil microbiome may play a significant or exclusive role in SM-induced disease suppression depending on the target pathogen and the plant species from which the SM was sourced (Mazzola et al. 2007; Weerakoon et al. 2012).

The rhizosphere microbiome influences function of innate and adaptive immunity of plants against infection by soilborne pathogens (Raaijmakers and Mazzola 2016). Brassicaceae SMand genotype-specific nature of the host rhizosphere can induce compositional changes in the microbiome. It was demonstrated that bacterial genera involved in sulfur oxidation and metabolizing of potential toxic organic compounds were more abundant in the rhizosphere of trees grown in SM-treated soil than that of the no treatment control (Mazzola et al. 2015). Additionally, the plant rhizosphere is inhabited by a unique population of microorganisms that are greatly influenced by host genetics (Aira et al. 2010; Bodenhausen et al. 2014), soil physicochemical properties (Aira et al. 2010), and addition of different types of fertilizer (Blaud et al. 2015). In return, the rhizosphere microbiome may act to moderate plant responses to various stresses, such as heat, drought, limited nutrient availability, and pest attack (Castillo Lopez et al. 2014; Johnson et al. 2015). Modifying the soil microbiome through Brassicaceae SM application and deploying the appropriate apple rootstock may provide prolonged suppression of the pathogen complex that incites apple replant disease.

Although a Brassicaceae SM formulation effective in control of replant disease has been identified (Mazzola and Brown 2010), grower adoption of the technology has been limited because of the greater treatment costs relative to preplant soil fumigation. Purchase and transport of SM to the orchard site are the primary costs associated with treatment application. Reduction in SM application rate will be a major factor in decreasing overall cost of this disease control tactic. In greenhouse trials, efficacy of reduced SM application rates was influenced by apple rootstock genotype (Wang and Mazzola 2019b). Application of this disease control tactic in the spring of planting would allow for greater ease of integration into orchard management systems. However, significant tree mortality was observed in previous trials with specific apple rootstocks when SM was applied in the spring of planting to orchard soils possessing low organic matter content (Mazzola et al. 2015). Therefore, this field study was conducted to evaluate reduced SM amendment rates when applied in the spring of orchard establishment in terms of replant disease control efficacy and phytotoxicity when integrated with rootstock genotypes differing in disease susceptibility/tolerance.

\section{MATERIALS AND METHODS}

Orchard sites. Studies were conducted at the Washington State University/U.S. Department of Agriculture-Agricultural Research
Service Columbia View Research and Demonstration (CV) Orchard located 12 miles north of East Wenatchee, Washington (N $47^{\circ}$ $\left.37^{\prime} 33^{\prime \prime}, \mathrm{W} 120^{\circ} 13^{\prime} 31^{\prime \prime}\right)$. The site was previously planted to apple (Malus domestica Borkh) cultivar Gala on rootstock M.26 (Mazzola and Brown 2010), and removal of the old orchard blocks was conducted in 2011. The dominant soil texture at CV orchard is Burch loam (Mazzola 1998) with a $\mathrm{pH}$ of 6.8, nitrogen at $19 \mathrm{mg}$ $\mathrm{kg}^{-1}$, phosphorus at $32 \mathrm{mg} \mathrm{kg}^{-1}$, sulfur at $4 \mathrm{mg} \mathrm{kg}^{-1}$, and an organic matter content of $2.1 \%$. The biological elements contributing to disease development at this site include Ilyonectria robusta, Rhizoctonia solani AG-5 and AG-6, Pythium ultimum, Pythium sylyaticum, Pythium irregulare, Pythium heterothallicum, Phytophthora cactorum, and Phytophthora cambivora (Mazzola 1998; Mazzola and Brown 2010; Mazzola et al. 2002). Although the root lesion nematode, $P$. penetrans, was not detected at significant populations in previous studies conducted at this site (Mazzola and Brown 2010; Mazzola and Mullinix 2005), the nematode was found to be prevalent during this study.

Brassicaceae SM. The SM formulation used in this study was a composite consisting of $B$. juncea 'Pacific Gold' and S. alba 'Ida Gold'. The glucosinolate contents in the B. juncea and S. alba SMs were 176.3 and $170.8 \mu \mathrm{mol} \mathrm{g}^{-1}$, respectively. The dominant glucosinolate in B. juncea SM was 2-propenyl glucosinolate, which yields the biologically active volatile AITC on hydrolysis, and the dominant glucosinolate in $S$. alba was 4-OH-benzyl, which yields 4-hydroxybenzyl ITC (Mazzola et al. 2015). The SM formulation was prepared by blending $B$. juncea and $S$. alba at a ratio of 1:1.

Orchard trial. The orchard trial used a split-plot experimental design, with soil treatment as the main effects plot. Each plot was 10.7-m long, with six replicates for each soil treatment, which consisted of SMs 2.2, 4.4, and $6.6 \mathrm{tha}^{-1}$; soil fumigation; and a no treatment control. The SM was applied only to the $1.52-\mathrm{m}$-wide strip that served as the orchard planting tree row. Each plot was planted with five Gala/M.26 and five Gala/G.41 trees, with the split plot applied in random order. Site preparation included tillage conducted in September 2015 before soil fumigation and was repeated in April 2016 immediately after SM application to the soil surface. Fumigation plots were treated with 1,3-dichloropropene/ chloropicrin at a rate of 252.6 liters ha ${ }^{-1}$ on 21 October 2015 to a depth of $46 \mathrm{~cm}$ by a commercial applicator (Trident Agriculture Products Inc.). SM was applied on 6 April 2016 within the $1.52-\mathrm{m}$ tree row width and incorporated to a depth of 15 to $20 \mathrm{~cm}$. The SMtreated plots were immediately tarped with plastic sheeting (152$\mu \mathrm{m}$-thick sheet; Sunbelt Plastics) to enhance retention of volatile glucosinolate hydrolysis products in the soil profile. Plastic was removed from plots 2 weeks after treatment. Soil temperature during treatment ranged from 12 to $14^{\circ} \mathrm{C}$. Immediately before tree planting, weed biomass was collected from three replicate $1-\mathrm{m}^{2}$ subplots within each treatment plot. The trial was planted to apple on 1 June 2016, with a spacing of $1 \mathrm{~m}$ between trees and $4.6 \mathrm{~m}$ between rows. Planting material consisted of 15-mm caliper Gala grafted to rootstock M.26 or G.41 obtained from a commercial nursery (Van Well Nursery).

Evaluation of tree growth and production. The effect of soil treatments on tree growth was assessed by monitoring the increase in tree stem diameter. Growth was assessed for the duration of the trial according to published protocols (Mazzola and Brown 2010). Briefly, the main stem was marked with latex paint $0.7 \mathrm{~m}$ above the soil line, and measurements of tree diameter were taken periodically over the course of three growing seasons using an electric caliper at two perpendicular directions to achieve a mean trunk diameter. Fruit harvest was conducted during the third growing season on 22 August 2018.

Soil and root collection for microbial analysis. Bulk soil samples were collected from all plots immediately before planting on 1 June 2016 ( 2 months after treatment). Soils were collected at two locations in each plot from a depth of 10 to $30 \mathrm{~cm}$. Rhizosphere soil and root samples were collected from two trees of each 
genotype from each split plot at 5 (end of the first growing season), 12 , and 17 months postplanting (end of the second growing season). Rhizosphere soil $(\sim 5 \mathrm{~g})$ was obtained by initially shaking off loosely adhering soil from tree roots and subsequently removing firmly adhering soil from fine roots using a sterile scalpel. Apple fine roots were cleaned by washing in tap water but without surface sterilization before processing for analysis of nematode and Pythium spp. root infection or DNA extraction.

Extractions of DNA from bulk soil, rhizosphere soil, and root samples were conducted using the MO BIO PowerMax Soil DNA Isolation Kit, the PowerSoil DNA Isolation Kit, and the UltraClean Plant DNA Isolation Kit (Mo Bio Laboratories), respectively. Abundance of fungal and bacterial DNA in bulk soil was assessed by quantitative polymerase chain reaction (PCR) as previously described (Reardon et al. 2013).

P. penetrans root densities were determined in October 2016 and October 2017 (5 and 17 months postplanting, respectively). Nematodes were extracted from a 0.5 -g fine root sample obtained from each sampled tree as previously described (Mazzola and Brown 2010). Nematodes were collected by passing the suspension twice through a 500- $\mu \mathrm{m}-\mathrm{mesh}$ sieve and then, backwashing into a counting dish. Numbers of $P$. penetrans were counted using a light microscope (40x magnification). Determination of apple root infection by Pythium spp. was conducted at 17 months after planting by placing 20 root segments $(0.5$ to $1.0 \mathrm{~cm}$ in length) from each root sample on Pythium semi-selective medium agar (Mazzola et al. 2001) as described previously (Mazzola 1998).

Terminal restriction fragment-length polymorphism (T-RFLP) analysis was utilized to profile bacterial and fungal communities in bulk soil samples collected before planting and samples of apple root tissue collected at 12 months after planting. Fluorescently labeled PCR products were generated by using labeled ITS1F/ ITS4 primers for amplifying the fungal internal transcribed spacer (ITS) region and 8f/907r primers for amplification of the bacterial $16 \mathrm{~S}$ ribosomal DNA region. Amplification reactions and T-RFLP analysis were conducted following the protocol as previously described (Weerakoon et al. 2012).

PCR amplification of rhizosphere DNA and Illumina sequencing. In total, DNA of 60 rhizosphere soil samples collected at 12 months after planting from five soil treatments (SM at 2.2, 4.4, and $6.6 \mathrm{t} \mathrm{ha}^{-1}$, fumigation, and control) and two rootstock genotypes (M.26 and G.41) was sequenced, with six replicates for each treatment combination. PCR amplification, purification, library preparation, and fungal/bacterial sequencing were conducted at an external facility (Molecular Research) on a MiSeq platform following the manufacturer's guidelines. Each sample was sequenced as a paired end set of reads, and sequence data were processed using an analysis pipeline as previously described (Mazzola et al. 2015). The reads were joined together after q25 trimming of the ends, and sequences that were $<150 \mathrm{bp}$ and ambiguous base calls were removed. Sequences were denoised, operational taxonomic units (OTUs) were generated, and chimers were removed. Final OTUs were classified taxonomically using BLASTn against a curated database derived from GreenGenes, RDPII, and NCBI (https:// www.ncbi.nlm.nih.gov/ and rdp.cme.msu.edu).

Data analysis. Statistical analyses were conducted using SAS (version 9.4; SAS Institute). Trunk diameter and yield measurements were analyzed using the SAS GLM model for split-plot design. Data were subjected to analysis of variance, and means separation was conducted using the Student-Newman-Keuls method. Percentage of Pythium spp. root infection and $P$. penetrans root density data were analyzed using Poisson regression (Gardner et al. 1995) (GENMOD model in SAS), and multiple comparisons were performed on soil treatment effects and rootstock genotype effects as well as interactions by using the least squares means statement in SAS, with $P \leq 0.05$ considered significant.

T-RFLP-derived microbial fragment data were compared by nonmetric multidimensional scaling using PAST software package version 3.16. The Dice similarity coefficient was calculated among groups of samples and used to perform ordination and one-way analysis of similarity (ANOSIM). Results with $P \leq 0.05$ were regarded as significant, with a large positive $R(\leq 1)$ signifying dissimilarity among groups (Hammer et al. 2001).

PAST and Explicet software (Robertson et al. 2013) was used to conduct statistical analysis and visualization of microbiome data. OTU data were refined by removing Archaea, chloroplast, mitochondrial sequences, singletons, and doubletons. The alpha diversity was determined using minimum library size as the cutoff size with 1,000 bootstrap resampling. Beta diversity was assessed by the Bray-Curtis dissimilarity index. A two-part test (Wagner et al.2011) was conducted after making filters for each bacterial and fungal library for each soil treatment and comparing them with each other, with a $P$ threshold of 0.05 .

\section{RESULTS}

Effect of SM amendment on the preplant bulk soil microbiome. The quantity of bacterial and fungal DNA detected in bulk soil samples at planting was significantly amplified in SMtreated soil relative to the control and fumigated soils (Table 1). There was no significant difference among SM treatments in quantity of bacterial or fungal DNA detected, and there was no difference between the control and fumigated soils. Composition of the bulk soil microbiome varied among soil treatments (Fig. 1). Structure of the SM 4.4 and $6.6 \mathrm{t} \mathrm{ha}^{-1}$ bulk soil bacterial community differed significantly $(P \leq 0.0076)$ from those of the control and fumigation treatments. The bulk soil bacterial community composition in SM 2.2-t ha ${ }^{-1}$ soil did not differ significantly $(P \geq 0.3193)$ from any other soil treatment. The bulk soil fungal community was highly similar $(P=0.1511, R=0.0953)$ between the control and fumigation treatments. Likewise, fungal community composition was highly similar $(P \geq 0.1161, R \leq 0.130)$ among all SM-treated soils regardless of SM application rate. The fungal community from SM-treated soils was dissimilar in composition from those in the control $(P \leq 0.0109, R \geq 0.5152)$ and fumigated $(P \leq 0.0026, R \geq$ $0.5833)$ soils.

Effect of preplant SM amendment on weed suppression and tree mortality. Significant weed suppression was observed at all SM amendment rates (Fig. 2), and mortality of Gala/M.26 was observed at the highest SM amendment rate during the initial growing season. The dominant weed species at this site included Taraxacum officinale (common dandelion), Poa annua (annual meadow grass), Capsella bursa-pastoris (shepherd's purse), Lamium amplexicaule (henbit dead nettle), Digitaria sanguinalis (hairy crabgrass), Holosteum umbellatum (jagged chickweed), Polygonum spp., Malva neglecta (common mallow), Stellaria media (common chicken weed), and Trifolium pretense (red clover). Weed biomass harvested from fumigated and control field plots before planting (2 months post-SM treatment) did not differ significantly. In contrast, irrespective of application rate, SM amendment significantly reduced weed biomass relative to the control and fumigated plots (Fig. 2). SM treatment had no significant $(P=0.480)$ effect on mortality of Gala/ G.41 trees during the initial growing season. However, SM applied at a rate of $6.6 \mathrm{t} \mathrm{ha}^{-1}$ resulted in $31.7 \%$ mortality of Gala/M.26 trees during the initial growing season, which was significantly greater than that observed in the fumigation $(7.6 \%, P=0.023)$ or control treatment $(11.7 \%, P=0.041)$ plots. SM applied at either 2.2 or $4.4 \mathrm{t}$ $\mathrm{ha}^{-1}$ did not significantly alter tree mortality relative to the fumigation $(P=0.260$ and $P=0.610$, respectively) or control $(P=0.410$ and $P=$ 0.900 , respectively) treatments.

Effect of SM amendment on tree growth and yield. Growth trends in terms of increase in Gala/G.41 and Gala/M.26 trunk diameter over three growing seasons are shown in Table 2. At the end of three growing seasons, Gala/G.41 trees established in SM-amended or -fumigated soil possessed a trunk diameter increment that was significantly greater $(P \leq 0.020)$ than that of 
trees cultivated in the untreated orchard replant soil (Table 2). There were no significant differences in Gala/G.41 trunk diameter increment among SM treatments $(P>0.167)$ or between soil fumigation and SM soil amendment $(P>0.082)$. For Gala/M.26 trees, only soil fumigation $(P=0.005)$ and $4.4-\mathrm{tha}^{-1} \mathrm{SM}(P=0.006)$ treatments significantly increased trunk diameter increment relative to the no treatment control.

All treatments, with the exception of $6.6 \mathrm{t} \mathrm{ha}^{-1}$ in conjunction with Gala/M.26, increased fruit yields relative to the no treatment control (Table 3). All SM treatments resulted in yields equivalent to that attained in response to preplant soil fumigation with the exception of Gala/M.26 cultivated in SM $6.6 \mathrm{t} \mathrm{ha}^{-1}$ and Gala/G.41 grown in SM $2.2 \mathrm{t} \mathrm{ha}^{-1}$.

Effect of SM amendment and rootstock genotype on disease control. Lesion nematode root densities were significantly

TABLE 1. Influence of soil treatment on quantity of fungal and bacterial DNA (picograms milligram ${ }^{-1}$ soil) detected in bulk soil as determined by real-time quantitative polymerase chain reaction immediately before planting at the Columbia View Research and Demonstration orchard

\begin{tabular}{lcc}
\hline Soil treatment & $\begin{array}{c}\text { Quantity of fungal } \\
\text { DNA }\end{array}$ & $\begin{array}{c}\text { Quantity of bacterial } \\
\text { DNA }\end{array}$ \\
\hline Control & $3.67 \mathrm{a}^{\mathrm{z}}$ & $2,404.67 \mathrm{a}$ \\
Telone-C35 & $2.94 \mathrm{a}$ & $1,847.44 \mathrm{a}$ \\
Bj/Sa SM 2.2 t ha-1 & $15.35 \mathrm{~b}$ & $3,740.72 \mathrm{~b}$ \\
$\mathrm{Bj} / \mathrm{Sa}$ SM 4.4 t ha & $17.24 \mathrm{~b}$ & $3,324.52 \mathrm{~b}$ \\
$\mathrm{Bj} / \mathrm{Sa}$ SM 6.6 t ha & $21.79 \mathrm{~b}$ & $3,282.33 \mathrm{~b}$ \\
\hline
\end{tabular}

y Seed meal (SM) treatments consisted of a 1:1 formulation of Brassica juncea (Bj)-Sinapis alba (Sa) applied in the spring of planting on 6 April 2016. Telone-C35 indicates 1,3-dichloropropene/chloropicrin fumigation. Bulk soil samples were collected 1 June 2016.

$\mathrm{z}$ Means in the same column followed by the same letter are not significantly $(P>0.05)$ different.
( $P \leq 0.034)$ lower for Gala/G.41 than Gala/M.26 at each sampling time point. At the end of the first growing season, all SM treatments and soil fumigation significantly reduced $P$. penetrans root densities recovered from Gala/G.41 and Gala/M.26 trees relative to the corresponding control $(P \leq 0.023)$ treatment (Table 4$)$. At the end of the second growing season, $P$. penetrans root densities were not significantly different for Gala/G.41 $(P=0.451)$ or Gala/M.26 $(P=0.179)$ trees cultivated in fumigated and control soils. However, sustained lesion nematode suppression was observed for all SM treatments, with significantly lower $P$. penetrans densities detected in roots of Gala/G.41 $(P \leq 0.039)$ and Gala/M.26 $(P \leq 0.032)$ relative to the control treatment at the end of the second growing season (Table 4).

The incidence of Pythium spp. root infection at the end of the second growing season was significantly $(P<0.05)$ reduced in response to SM and fumigation treatments (Fig. 3) relative to the control. No significant difference was observed among SM treatments or between SM and fumigation treatments in suppression of Pythium spp. root infection (Fig. 3). When compared between rootstock genotypes, a significantly greater incidence of Pythium spp. root infection was observed for Gala/ G.41 than Gala/M.26 trees cultivated in the control $(P=0.021)$ or fumigated $(P=0.046)$ soils. However, there was no significant $(P \geq$ 0.202) difference in Pythium spp. root infection between rootstock genotypes when trees were cultivated in SM-treated soils (Fig. 3).

T-RFLP analysis of apple root microbiome at 1 year postplanting. Based on T-RFLP profiles, soil treatment effects on fungal community composition in apple roots 1 year postplanting were more pronounced from Gala/G.41 $(R=0.488)$ than Gala/M.26 $(R=0.365)$ (Fig. 4). Fungal community composition in roots of Gala/G.41 planted in all SM-amended soils was distinct $(P \leq$ $0.0054 ; R \geq 0.528$ ) from those in the fumigation and control treatments (Fig. 4A). The root fungal community composition from the SM treatments became increasing dissimilar from the control or

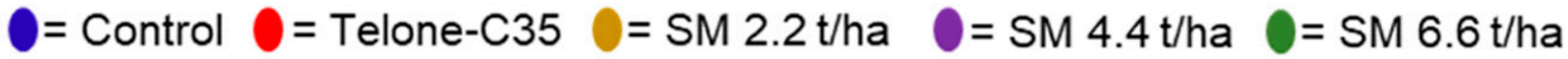
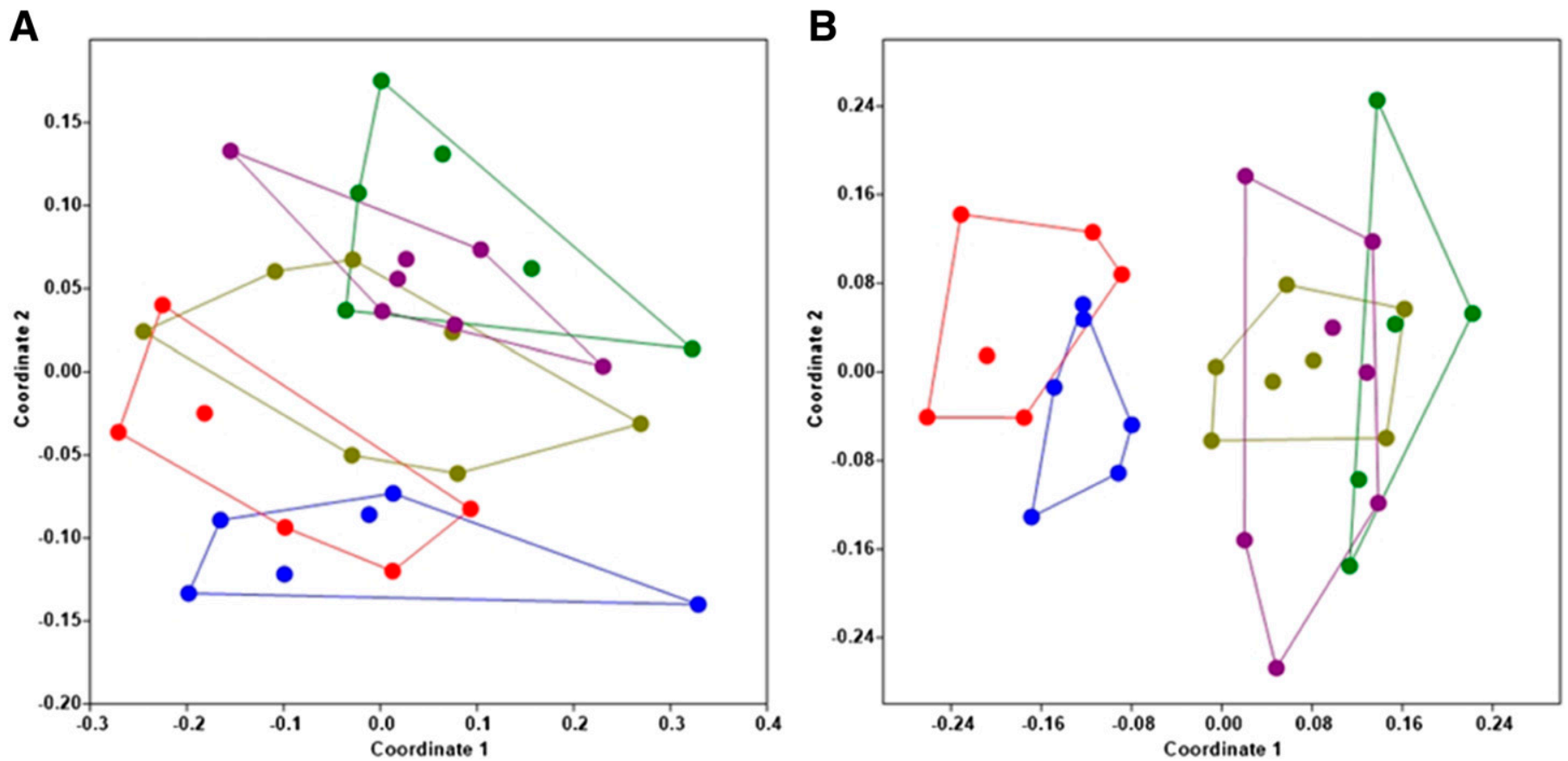

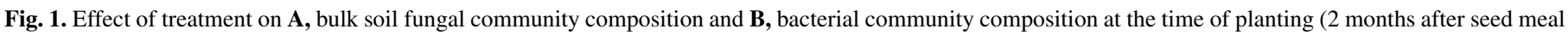

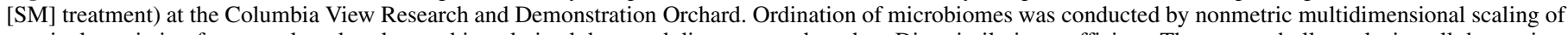

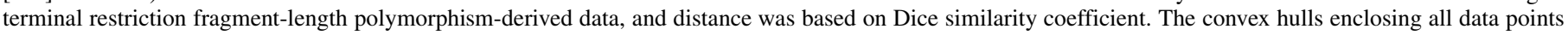

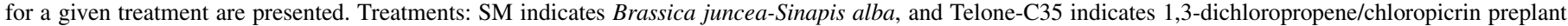
soil fumigation. 
fumigated treatments with increasing SM amendment rate. Maximum dissimilarity in Gala/G.41 root fungal community composition was observed between the fumigation and SM 6.6-t ha $\mathrm{h}^{-1}$ treatments ( $P=0.0021 ; R=0.9593)$. No significant difference was observed between the control and fumigation treatments $(P=0.139)$. Roots of Gala/M.26 from the SM 6.6-t ha ${ }^{-1}$ treatment possessed a fungal community that was similar to the fumigation $(P=0.083)$ and control $(P=0.331)$ treatments. In contrast, the fungal community detected in roots of Gala/M.26 cultivated in SM 2.2- and SM 4.4-t ha ${ }^{-1}$ treated soils differed $(P \leq 0.0168)$ from all other treatments (Fig. 4C).

For all SM treatments, structure of the bacterial community in roots of Gala/G.41 treatments differed significantly $(P \leq 0.0094)$ from that detected in the fumigation and control treatments (Fig. 4B), with $R_{\text {ANOSIM }}$ increasing from 0.4796 to 0.872 at increasing $\mathrm{SM}$ amendment rate. Composition of the bacterial community in roots of Gala/M.26 cultivated in 4.4- and 6.6-t ha ${ }^{-1}$ SM-treated soil was similar $(P=0.069)$ but differed significantly $(P=0.002$ and $P=0.004$, respectively) from the control treatment (Fig. 4D). In contrast to Gala/G.41, only Gala/M.26 cultivated in 4.4-t ha ${ }^{-1}$ SMamended soil possessed a root bacterial community that differed from that of trees cultivated in fumigated soil $(P=0.0017, R=$ $0.7204)$. The bacterial community detected in roots of Gala/M.26 grown in SM at 2.2-t ha ${ }^{-1}$ soil did not differ significantly from either the control $(P=0.270)$ or the fumigation $(P=0.517)$ treatment (Fig. 4D). Bacterial community composition in roots of Gala/G.41

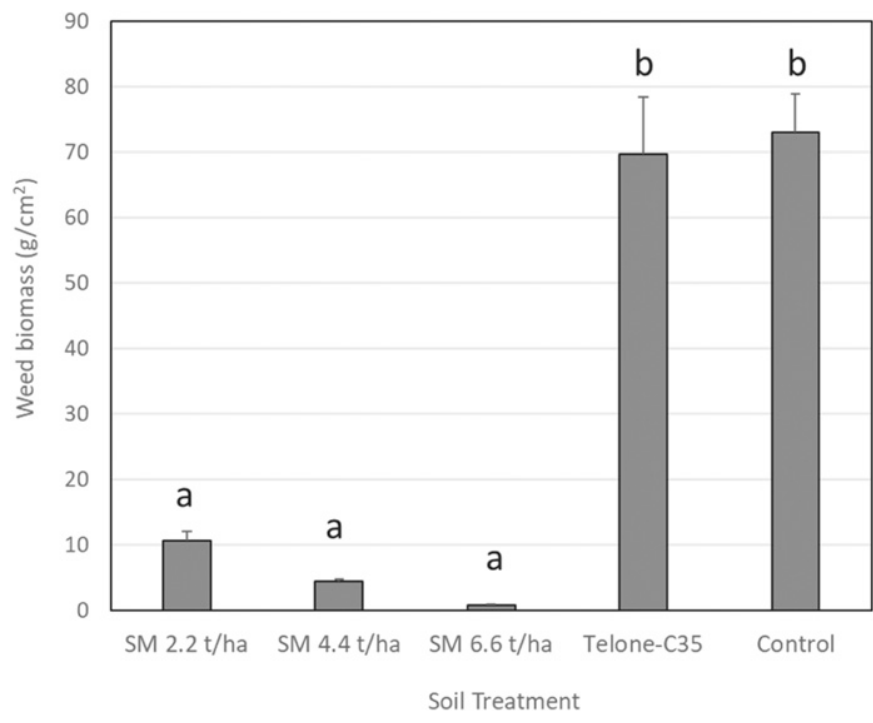

Fig. 2. Effect of seed meal (SM) application rate on weed biomass (dry weight) recovered from the Columbia View Research and Demonstration Orchard field trial at 2 months after SM treatment. Bars indicate one standard error of the mean. Treatments: SM indicates Brassica juncea-Sinapis alba, and Telone-C35 indicates 1,3-dichloropropene/chloropicrin preplant soil fumigation.

TABLE 2. Increase in apple tree trunk diameter (millimeters) over three growing seasons on a replant site at the Columbia View Research and Demonstration Orchard, Orondo, Washington

\begin{tabular}{lcc}
\hline & \multicolumn{2}{c}{ Rootstock } \\
\cline { 2 - 3 } Soil treatment ${ }^{\mathrm{y}}$ & Gala/M.26 & Gala/G.41 \\
\hline Control & $14.97 \mathrm{a}^{\mathrm{z}}$ & $12.32 \mathrm{a}$ \\
Telone-C35 & $19.21 \mathrm{~b}$ & $15.85 \mathrm{~b}$ \\
Bj/Sa SM 2.2 t ha & $16.90 \mathrm{ab}$ & $15.82 \mathrm{~b}$ \\
Bj/Sa SM 4.4 t ha-1 & $18.78 \mathrm{~b}$ & $17.98 \mathrm{~b}$ \\
Bj/Sa SM 6.6 t ha & $14.04 \mathrm{a}$ & $18.04 \mathrm{~b}$ \\
\hline
\end{tabular}

y Seed meal (SM) treatments consisted of a 1:1 formulation of Brassica juncea (Bj)-Sinapis alba (Sa) applied in the spring of planting on 6 April 2016. Telone-C35 indicates 1,3-dichloropropene/chloropicrin fumigation.

${ }^{\mathrm{z}}$ Means in the same column followed by the same letter are not significantly $(P>0.05)$ different.
( $R=0.437$ ) exhibited greater dissimilarity among soil treatments than did communities in the roots of Gala/M.26 $(R=0.255)$.

Composition of the rhizosphere soil microbiome 1 year postplanting. Rhizosphere fungal communities differed among soil treatments and between rootstock genotypes in terms of OTU content and species richness (Table 5). A decrease in the number of fungal OTUs detected in the rhizosphere was observed with an increase in SM application rate, and the number of OTUs was lower in all SM treatments relative to the control (Table 5). SM treatments resulted in rhizosphere fungal communities having lower Chao 1 indices, a measure of species richness, than the control treatment, and the Chao 1 index decreased with increasing SM application rate (Table 5). These variations were consistent for both M.26 and G.41 rootstock. In general, the number of bacterial OTUs detected in the apple rhizosphere decreased with increasing SM amendment rate (Table 6). This was associated with a slight decrease in alpha diversity as estimated by the Chao 1 index. Bacterial diversity in the rhizosphere was greater in the control and fumigation treatments relative to the SM 6.6-t ha ${ }^{-1}$ treatment (Table 6).

ANOSIM among fungal OTUs indicated that rhizosphere fungal community compositions in the control and fumigation treatments were more similar to each other but distinct from those of the SM treatments (Fig. 5). The SM soil treatment effects on rhizosphere fungal community structure were consistent across the two apple rootstock genotypes (Fig. 5A and C). ANOSIM indicated that the control and fumigation treatments possessed rhizosphere fungal communities that were somewhat dissimilar for M.26 $(P=0.0019$, $R=0.4093)$ but highly similar for $\mathrm{G} .41(P=0.1715, R=0.08333)$. The rhizosphere fungal community composition of Gala/M.26 $(P \leq$ $0.0049, R \geq 0.3759)$ and Gala/G.41 $(P \leq 0.0025, R \geq 0.5852)$ planted in SM 2.2-t ha ${ }^{-1}$ soil was dissimilar from that detected in the rhizosphere of trees grown in SM 4.4- or 6.6-t ha-1 soil. For a given rootstock, rhizosphere fungal communities were highly similar when cultivated in 4.4- or 6.6-t ha ${ }^{-1} \mathrm{SM}$-amended soil (M.26: $P=$ $0.2125, R=0.07963$; G.41: $P=0.0694, R=0.1759$ ).

As observed for fungal communities, the rhizosphere bacterial communities from the control and fumigation treatments were similar in structure (M.26: $P=0.0898, R=0.1778$; G.41: $P=0.321$, $R=0.2593$ ). Rhizosphere bacterial community composition from SM treatments was dissimilar from that detected in the control or fumigation treatment irrespective of SM amendment rate or rootstock genotype (Fig. 5B and D). Trees cultivated in 4.4- and 6.6-t ha $\mathrm{a}^{-1} \mathrm{SM}-$ treated soils possessed highly similar rhizosphere bacterial communities (M.26: $P=0.4295, R=0.0148$; G.41: $P=0.1584, R=0.0925$ ), which differed from that detected in the 2.2- $\mathrm{t} \mathrm{ha}^{-1} \mathrm{SM}$ treatment. When examined across rootstock genotype, the rhizosphere bacterial communities from Gala/G.41 and Gala/M.26 planted in fumigated or control soils were similar, but differences in community composition between genotypes were apparent when cultivated in SM-amended soil (Fig. 6). This was particularly notable when comparing bacterial community similarity between rootstocks planted in soils amended with SM at 4.4 or $6.6 \mathrm{t} \mathrm{ha}^{-1}$ (Fig. 6).

TABLE 3. Yield (kilograms tree ${ }^{-1}$ ) of Gala apple on a replant site at the Columbia View Research and Demonstration Orchard, Orondo, Washington

\begin{tabular}{lcc}
\hline & \multicolumn{2}{c}{ Rootstock } \\
\cline { 2 - 3 } Soil treatment ${ }^{\mathrm{y}}$ & Gala/M.26 & Gala/G.41 \\
\hline Control & $5.21 \mathrm{a}^{\mathrm{z}}$ & $5.12 \mathrm{a}$ \\
Telone-C35 & $7.06 \mathrm{~b}$ & $8.41 \mathrm{c}$ \\
Bj/Sa SM 2.2 t ha & $7.01 \mathrm{~b}$ & $6.86 \mathrm{~b}$ \\
Bj/Sa SM 4.4 t ha-1 & $7.23 \mathrm{~b}$ & $8.61 \mathrm{c}$ \\
Bj/Sa SM 6.6 t ha & $4.85 \mathrm{a}$ & $8.43 \mathrm{c}$ \\
\hline
\end{tabular}

y Seed meal (SM) treatments consisted of a 1:1 formulation of Brassica juncea (Bj)-Sinapis alba (Sa) applied in the spring of planting on 6 April 2016. Telone-C35 indicates 1,3-dichloropropene/chloropicrin fumigation.

${ }^{\mathrm{z}}$ Means in the same column followed by the same letter are not significantly $(P>0.05)$ different. 
At 1 year after planting, the Ascomycota represented the greatest proportion (47 to $71 \%$ ) of the fungal community detected in the rhizosphere of apple trees planted in SM-treated soils; however, fungal phylum Zygomycota was represented at the greatest frequency ( 38 to $43 \%$ ) in the fumigation and control treatments (Fig. 7A). More specifically, the class Sordariomycetes represented a greater proportion of the rhizosphere fungal community in the SM treatments relative to the control and fumigation treatments, and the proportion increased with an increase in SM application rate. In contrast, Mortierellomycotina, a subphylum within Zygomycota, comprised a greater proportion of the fungal community in the control and fumigation treatments than in SM treatments. The Basidiomycota represented a greater proportion of the fungal community observed in the rhizosphere of Gala/G.41 cultivated in SM and control treatments relative to Gala/M.26 in the same soils.

The genus Chaetomium, including Chaetomium globosum, Chaetomium gracile, and Chaetomium nigricolor, was consistently more abundant in the rhizosphere of apple cultivated in SM-treated soil than the control irrespective of rootstock genotype and SM amendment rate. The genus Trichoderma (teleomorph Hypocrea), including Trichoderma asperellum, Trichoderma hamatum, Hypocrea ceramica, and Hyprocrea longipilosa, was also significantly $(P<0.05)$ more abundant in the rhizosphere of Gala/M.26 cultivated in 2.2- and 4.4-t ha ${ }^{-1}$ SM-amended soil than in the control. Similarly, Hypocrea virens, T. hamatum, and Hypocrea lixii were more abundant in the rhizosphere of Gala/G.41 planted in SMamended soil than the control or fumigated orchard soil. In Gala/ G.41 rhizosphere soil, Apodus oryzae, Diaporthe phoenicicola, and Thielavia spp. were significantly $(P<0.05)$ more abundant in SMtreated soil than in the control soil. Certain species were found in greater abundance with increasing rate of SM amendment, such as Gelasinospora brevispora and Gelasinospora cratophora.

Various fungal elements reported to possess significant plantmicrobe associations were differentially abundant across soil treatments. The abundance of several pathogens reported to have a role in replant disease, including I. robusta and Rhizoctonia spp., was greater $(P<0.05)$ in the rhizosphere of apple cultivated in control and fumigated soil relative to SM treatments. Fusarium spp., including Fusarium lateritium, Fusarium polyphialidicum, and Fusarium oxysporum, were more abundant $(P<0.05)$ in the control treatment compared with SM 4.4- and 6.6-t ha ${ }^{-1}$ treatments. The abundance of several potential postharvest pathogens, including Alternaria alternata, Penicillium spp., and Glomerella spp., were significantly $(P<0.05)$ more abundant in rhizosphere soil from the control than SM treatment. In contrast, several arbuscular mycorrhizal fungi of the Glomeromycota, including Entrophospora spp., Glomus indicum, Glomus versiforme, Diversispora spuraca, Funneliformis mosseae, Rhizophagus intraradices, and Rhizophagus irregularis, were observed at significantly $(P<0.05)$ greater abundance in the control than SM treatments. In addition, the

TABLE 4. Density (number gram ${ }^{-1}$ root) of Pratylenchus penetrans recovered from roots of Gala/M.26 and Gala/G.41 apple as influenced by soil treatment at the Columbia View Research and Demonstration Orchard, Orondo, Washington

\begin{tabular}{|c|c|c|c|c|}
\hline \multirow[b]{2}{*}{ Soil treatment ${ }^{\mathrm{y}}$} & \multicolumn{2}{|c|}{ October 2016} & \multicolumn{2}{|c|}{ October 2017} \\
\hline & Gala/M.26 & Gala/G.41 & Gala/M.26 & Gala/G.41 \\
\hline Control & $1,247 b^{z}$ & $756 \mathrm{~b}$ & $2,142 \mathrm{~b}$ & $997 \mathrm{~b}$ \\
\hline Telone-C35 & $400 \mathrm{a}$ & $234 \mathrm{a}$ & $1,335 \mathrm{ab}$ & $758 \mathrm{~b}$ \\
\hline $\mathrm{Bj} / \mathrm{Sa} \mathrm{SM} 2.2 \mathrm{t} \mathrm{ha}^{-1}$ & $166 \mathrm{a}$ & $99 \mathrm{a}$ & $513 \mathrm{a}$ & $231 \mathrm{a}$ \\
\hline $\mathrm{Bj} / \mathrm{Sa} \mathrm{SM} 4.4 \mathrm{t} \mathrm{ha}^{-1}$ & $10 \mathrm{a}$ & $78 \mathrm{a}$ & $530 \mathrm{a}$ & 76 a \\
\hline $\mathrm{Bj} / \mathrm{Sa} \mathrm{SM} 6.6 \mathrm{t} \mathrm{ha}^{-1}$ & $98 \mathrm{a}$ & $29 \mathrm{a}$ & $568 \mathrm{a}$ & $88 \mathrm{a}$ \\
\hline
\end{tabular}

y Seed meal (SM) treatments consisted of a 1:1 formulation of Brassica juncea

(Bj)-Sinapis alba (Sa) applied in the spring of planting on 6 April 2016.

Telone-C35 indicates 1,3-dichloropropene/chloropicrin fumigation.

${ }^{\mathrm{z}}$ Means in the same column followed by the same letter are not significantly $(P>0.05)$ different. abundance of Entrophospora spp. and the endophyte Preussia spp. (Mapperson et al. 2014; Supaphon et al. 2013) decreased with increasing SM application rate.

Among bacterial phyla, Gemmatimonadetes, Firmicutes, Fusobacteria, and Armatimonadetes were detected at greater abundance in the rhizosphere of trees cultivated in SM-treated soil relative to the control and fumigated soils (Fig. 7B), whereas the phyla Chloroflexi, Planctomycetes, Nitrospirae, and Elusimicrobia were detected at lower frequencies in SM-treated soils than the control and fumigated soils (Fig. 7B). Among the firmicutes, multiple species within the genus Bacillus, including those classified as Bacillus aquimaris, Bacillus aryabhattai, Bacillus badius, Bacillus beringensis, Bacillus flexus, Bacillus ginsengi, Bacillus selenatarsenatis, Bacillus thuringiensis, Bacillus weihenstephanensis, Bacillus vireti, and Bacillus subtilis, were detected at significantly $(P<0.05)$ greater abundance in the rhizosphere of apple trees cultivated in SM-treated soil compared with control or fumigated soil. In addition, the genera Paenibacillus and Terribacillus were represented at greater frequencies $(P=0.016$ and 0.029, respectively) in the rhizosphere of apple grown in SMamended soil. Bacterial genera with a known capacity to metabolize potential toxic organic compounds, such as the genera Pusillimonas (Hilyard et al. 2008; Lee et al. 2011), Shinella (Bai et al. 2009), and Rhodococcus (Kuyukina and Ivshina 2010), were found at significantly $(P<0.05)$ greater abundance in the SM treatment compared with the control. In addition, several bacterial species within genera that are widely used as biocontrol agents, such as the genera Streptomyces and Sphingomonas (White et al. 1996), were significantly more abundant $(P<0.05)$ in the rhizosphere of apple trees planted in SM-amended soil than the control or fumigated soil. In contrast, bacterial genera that have function in nitrogen cycling and sulfur cycling were detected at significantly $(P<0.05)$ greater abundance in the control treatment than in SM treatments.

\section{DISCUSSION}

Effective long-term soilborne pathogen suppression is of significant value in perennial crop production systems. Limitations to the use of preplant soil fumigation in commercial orchards, such as the rapid reinfestation of fumigated soils by root lesion nematode, have been identified (Mazzola et al. 2015). The short-term benefits of soil fumigation in pathogen and pest control do not fulfill the need for obtaining optimal yields in perennial crops. Alternative methods, including compost applications (Braun et al. 2010; Franke-Whittle

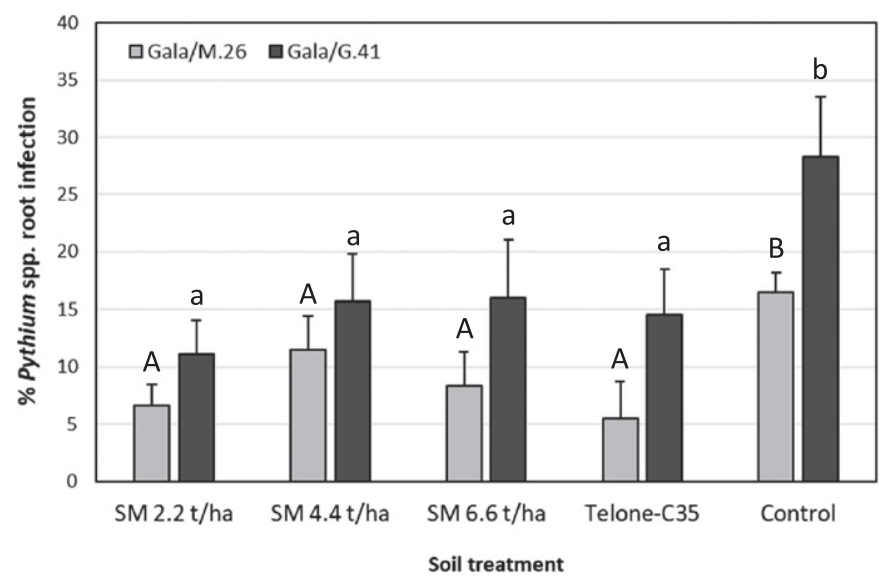

Fig. 3. Effect of soil treatment on infection of Gala/M.26 and Gala/G.41 apple roots by Pythium spp. at the end of the second growing season (17 months after planting) in the field trial conducted at the Columbia View Research and Demonstration Orchard. Bars indicate one standard error of the mean. For a given rootstock genotype, bars designated with the same letter indicate means that are not significantly different based on the least squares means statement. Treatments: Seed meal (SM) indicates Brassica juncea-Sinapis alba, and TeloneC35 indicates 1,3-dichloropropene/chloropicrin preplant soil fumigation. 
et al. 2018), fertility management programs (Slykhuis and Li 1985), and use of tolerant rootstocks (Auvil et al. 2011; Robinson et al. 2014; Rumberger et al. 2004), have lacked consistency for the control of replant disease. This study in concert with previous field trials (Mazzola and Mullinix 2005; Mazzola et al. 2015) demonstrated the effectiveness of the preplant application of a Brassicaceae SM formulation for the control of apple replant disease across both organic and conventional production systems. In previous research, SM was applied at a rate of $6.6 \mathrm{t} \mathrm{ha}^{-1}$ in research orchards, commercial orchards, or greenhouse trials (Mazzola et al. 2015), resulting in treatment cost of $\$ 5,000$ to $13,000 \mathrm{ha}^{-1}$, which is approximately three times the cost of conventional soil fumigation. Despite the efficacy of SM treatments on tree growth, yield, and pathogen suppression, investment costs associated with treatment application have served as an obstacle to commercial adoption of this disease control strategy. Significantly increased yields associated with SM application relative to soil fumigation (Mazzola et al. 2015) may alleviate reluctance to utilize SM as a disease control tactic; however, a reduced treatment cost will have a greater potential to stimulate grower adoption.

In addition to cost, capacity to utilize a treatment that fits easily into an orchard management program is a major factor that will

\section{$0=$ Control $0=$ Telone $-\mathrm{C} 35=\mathrm{SM} 2.2 \mathrm{t} / \mathrm{ha} \quad \mathrm{O}=\mathrm{SM} 4.4 \mathrm{t} / \mathrm{ha} \quad 0=\mathrm{SM} 6.6 \mathrm{t} / \mathrm{ha}$}

A

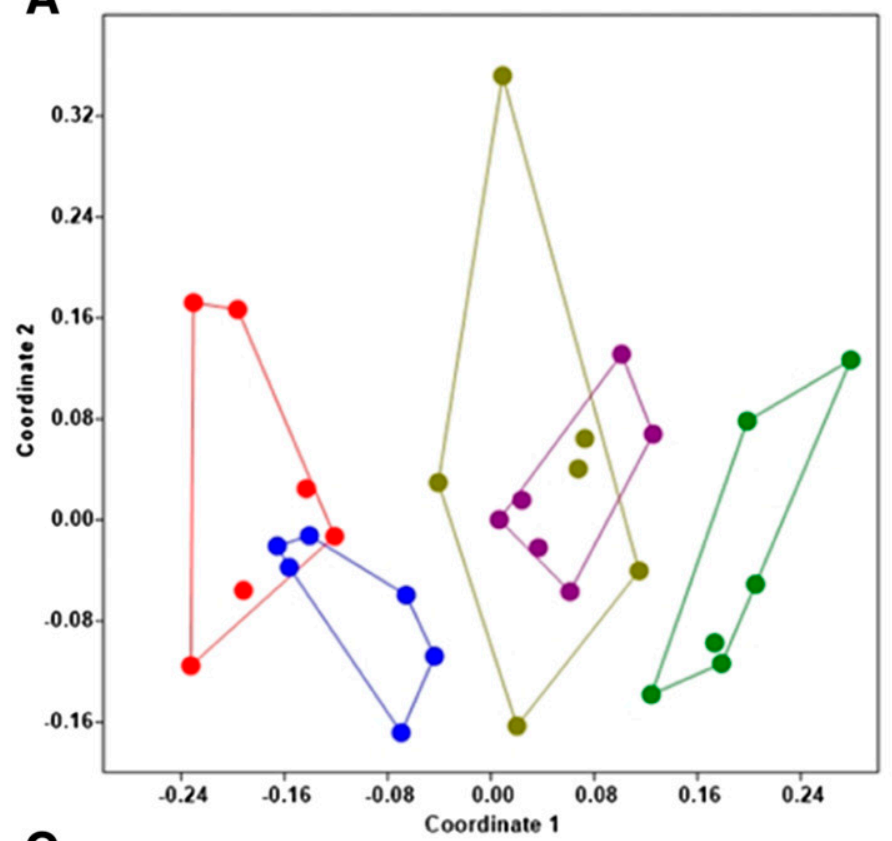

C

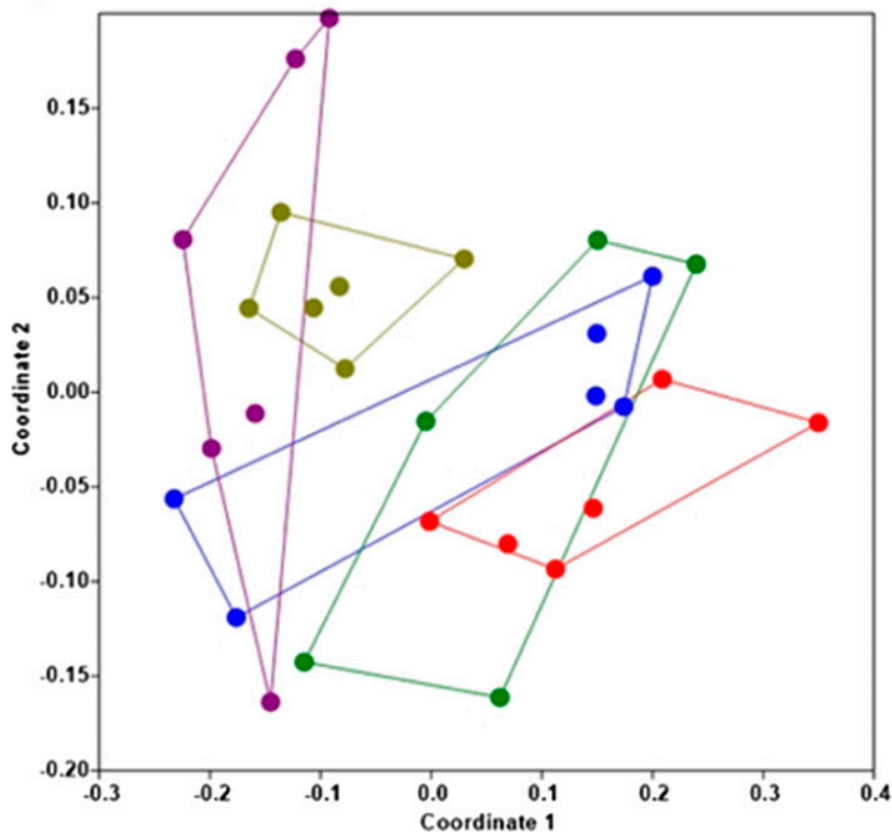

B

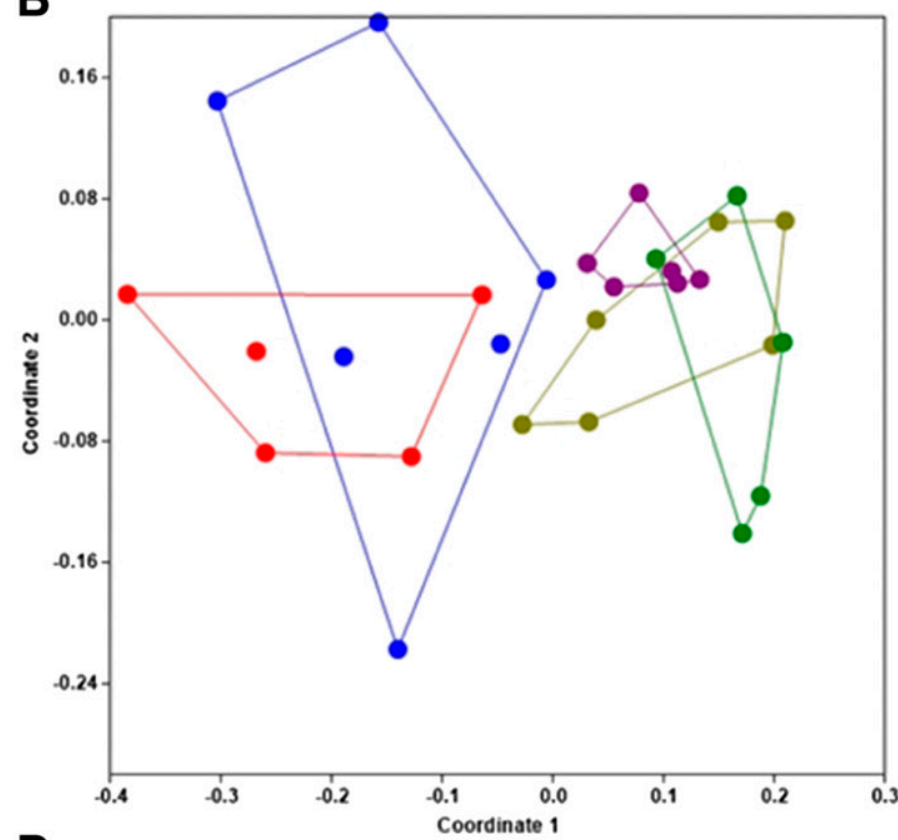

D

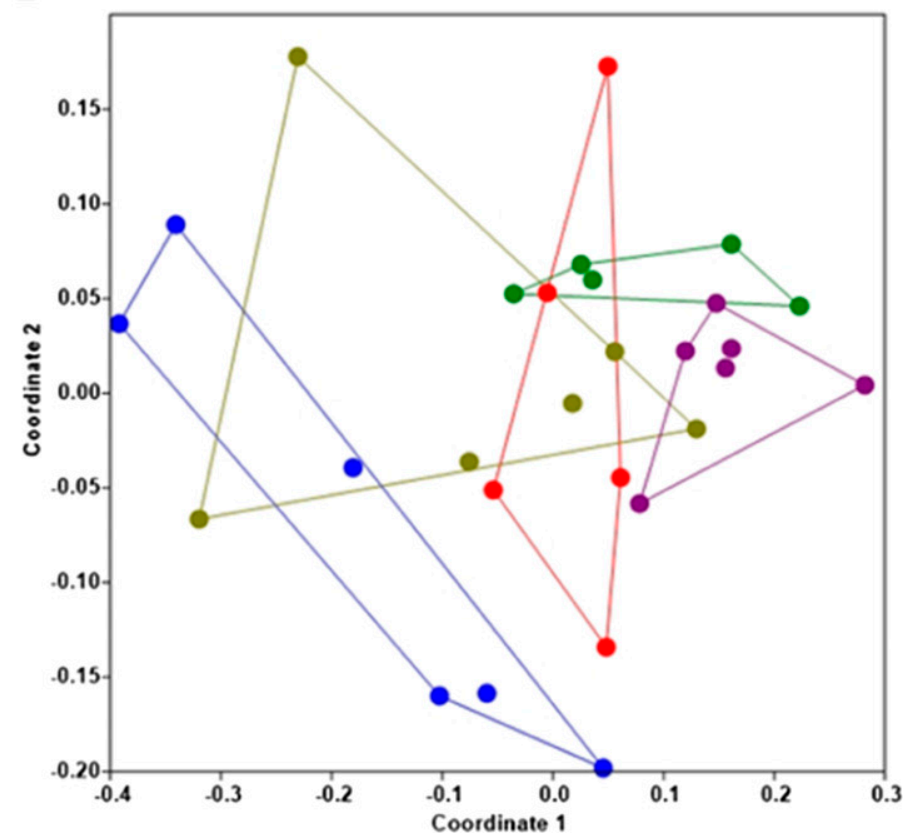

Fig. 4. Effect of soil treatment on composition of the microbiome detected in roots of Gala/G.41 (A, fungi and B, bacteria) and Gala/M.26 (C, fungi and D, bacteria) 1 year postplanting at the Columbia View Research and Demonstration Orchard. Ordination of microbiomes in roots was conducted by nonmetric multidimensional scaling of terminal restriction fragment-length polymorphism-derived data, and distance was based on Dice similarity coefficient. The convex hulls enclosing all data points for a given treatment are presented. Treatments: Seed meal (SM) indicates Brassica juncea-Sinapis alba, and Telone-C35 indicates 1,3-dichloropropene/chloropicrin preplant soil fumigation. 
influence grower adoption. Application in the spring of planting is highly desired because of the limited time available after fruit harvest, tree removal, site preparation, and treatment application in the autumn before orchard renewal the next spring. Because of potential phytotoxicity (Meyer et al. 2011; Rothlisberger et al. 2012), determination of requisite intervals between treatment and planting and effective minimal application rate are essential before the use of Brassicaceae SMs for soilborne disease control. In a previous trial, significant tree death was observed during the first growing season for trees planted in soil treated with the $B$. juncea-S. alba SM amendment in the spring of planting (Mazzola et al. 2015). Elevated tree mortality was not observed in soils receiving the same SM treatment in the autumn before planting. In addition, phytotoxicity was more apparent on Gala/M.9 than Gala/G.11 trees. Demonstrated efficacy of a reduced SM application rate not only would improve the economics of the treatment relative to soil fumigation but also, may minimize the potential for phytotoxic effects of a spring of planting SM treatment.

Brassicaceae SM formulations applied as a preplant soil amendment at a rate of $6.6 \mathrm{t} \mathrm{ha}^{-1}$ resulted in apple tree growth and yield on replant orchard sites that were equivalent to those attained in response to preplant soil fumigation with 1,3-dicloropropene/ chloropicrin (Mazzola and Brown 2010; Mazzola et al. 2015). In this study, a reduced SM application rate $\left(4.4 \mathrm{t} \mathrm{ha}^{-1}\right)$ resulted in tree growth performance and disease suppression that was equivalent or even superior to that of the highest SM application rate $\left(6.6 \mathrm{t} \mathrm{ha}^{-1}\right)$, resulting in a one-third reduction in treatment application cost $\left(\sim \$ 1,700\right.$ to $\left.4,000 \mathrm{ha}^{-1}\right)$. Significant phytotoxicity was observed for Gala/M.26 trees but not Gala/G.41 trees planted in soils treated with $\mathrm{SM}$ in the spring 8 weeks posttreatment at the rate of $6.6 \mathrm{t} \mathrm{ha}^{-1}$; however, phytotoxicity was not observed at the two lower SM amendment rates $\left(2.2\right.$ and $\left.4.4 \mathrm{tha}^{-1}\right)$. At the end of three growing seasons, the SM 6.6-t ha ${ }^{-1}$ treatment had not significantly increased growth of Gala/M.26 relative to the control treatment, likely as a result of the extensive tree mortality and growth suppression during the initial growing season.

Growth increment of apple trees grafted to rootstock G.41 was similar for the 4.4- and 6.6-t ha ${ }^{-1} \mathrm{SM}$ treatments. In contrast, Gala/ M.26 exhibited superior growth in 4.4- than 6.6-t ha-1 SM-treated soil. This finding suggests that G.41 was less susceptible than M.26 to the phytotoxic effects of the SM amendment when applied at the highest rate. Similarly, when a $B$. juncea-B. napus SM formulation was implemented at a rate of $6.6 \mathrm{t} \mathrm{ha}^{-1}$, significantly greater tree growth was observed when used in conjunction with Gala/G.11 compared with Gala/M.9 (Mazzola et al. 2015). Thus, in terms of tree growth, results from this study indicated that, when applied in spring of planting, the SM 4.4-t ha ${ }^{-1}$ treatment is equivalent (when used in conjunction with G.41) or even superior (when applied in conjunction with M.26) to the SM 6.6-t ha ${ }^{-1}$ treatment for effective disease control and maintenance of orchard productivity.

TABLE 5. Attributes of apple rhizosphere fungal community diversity based on relative abundance of operational taxonomic units (OTUs) ${ }^{\mathrm{x}}$

\begin{tabular}{llcc}
\hline Rootstock & Soil treatment ${ }^{\mathrm{y}}$ & Number of OTUs & Chao 1 \\
\hline M.26 & Control & $318 \pm 23$ & $407 \pm 26$ \\
G.41 & Control & $286 \pm 27$ & $371 \pm 31$ \\
M.26 & Telone-C35 & $261 \pm 59$ & $351 \pm 71$ \\
G.41 & Telone-C35 & $245 \pm 67$ & $318 \pm 76$ \\
M.26 & SM 2.2 t ha-1 & $283 \pm 49$ & $369 \pm 55$ \\
G.41 & SM 2.2 t ha & $370 \pm 40$ \\
M.26 & SM 4.4 t ha & $282 \pm 37$ & $319 \pm 29$ \\
G.41 & SM 4.4 t ha & $236 \pm 26$ & $2811 \pm 18$ \\
M.26 & SM 6.6 t ha-1 & $230 \pm 16$ & $298 \pm 61$ \\
G.41 & SM 6.6 t ha-1 & $202 \pm 31$ & \\
\hline
\end{tabular}

$x$ An OTU is defined as sequences sharing $>97 \%$ similarity.

$\mathrm{y}$ Treatment designations are as follows: control indicates no treatment control, seed meal (SM) indicates Brassica juncea-Sinapis alba, and TeloneC35 indicates 1,3-dichloropropene/chloropicrin fumigation.

${ }^{z}$ Data are indicated as the mean \pm standard deviation $(n=6)$.
When B. juncea SM was incorporated into soil at a rate of $3.36 \mathrm{t}$ $\mathrm{ha}^{-1}$, the emergence of orchard weeds and turf grass was reduced $>63 \%$ relative to the no treatment control (Earlywine et al. 2010). However, when applied at a lower application rate $\left(1.35 \mathrm{t} \mathrm{ha}^{-1}\right)$, the SM treatment only reduced the incidence of particular weed species, such as Plantago lanceolate L, Trifolium repens $\mathrm{L}$, and S. media (L) Vill (Earlywine et al. 2010). In contrast, SM of $B$. juncea and $S$. alba used alone or in combination did not suppress weed populations in tomato beds relative to a fertilizer-only treatment at the relatively low application rates of 0.95 to $1.9 \mathrm{t} \mathrm{ha}^{-1}$ (Meyer et al. 2015). These and other studies (Handiseni et al. 2011; Rothlisberger et al. 2012) indicate that weed control in response to incorporation of Brassicaceae SM is application rate and weed species dependent. However, in this study, preplant SM amendment resulted in effective weed control relative to fumigation and control treatments across all application rates. Preplant 1,3-dichloropropene/ chloropicrin soil fumigation did not significantly suppress weed development and has failed to effectively control weeds in other crop production systems (Hanson and Shrestha 2006). Findings from this and other studies indicate a significant additional benefit of the SM treatment, because newly established crop plantings, including orchards, are susceptible to growth suppression from weed competition.

Soilborne disease control in response to Brassicaceae SM soil amendment is attained through various biological and chemical functional pathways (Cohen et al. 2005). Previous observations indicated that glucosinolate content and generation of ITCs are not the singular determinants of disease suppression attained in response to rotation with Brassica crops (Larkin and Honeycutt 2006) or soil incorporation of Brassicaceae residues (Larkin and Griffin 2007). Similarly, the efficacy of B. napus SM in the suppression of root lesion nematode (Mazzola et al. 2001) and $R$. solani root infection (Cohen et al. 2005) was shown to function irrespective of the production of biologically active glucosinolate hydrolysis products. Orchard history at the site of this study indicates a significant increase in $P$. penetrans populations relative to those previously documented (Mazzola and Brown 2010), which contributed significantly to overall disease development in this study. All SM application rates used in this study effectively suppressed the incidence of root lesion nematode and Pythium spp. root infection relative to the control. Although AITC has demonstrated nematicidal activity toward a spectrum of plant parasitic nematodes (Yu et al. 2005), long-term nematode suppression has not been documented previously, and it has not been observed in extended field trials in perennial crops. A preplant B. juncea SM treatment did not provide effective control of $P$. penetrans in red raspberry when broadcast applied to the field at a rate of $3.4 \mathrm{t} \mathrm{ha}^{-1}$ (Rudolph et al. 2019), which is substantially lower than the functional rates used in this study that were applied to only

TABLE 6. Attributes of apple rhizosphere bacterial community diversity based on relative abundance of operational taxonomic units (OTUs) ${ }^{\mathrm{x}}$

\begin{tabular}{llcc}
\hline Rootstock & Soil treatment $^{\mathrm{y}}$ & Number of OTUs $^{\mathrm{z}}$ & Chao 1 \\
\hline M.26 & Control & $918 \pm 21$ & $1,163 \pm 33$ \\
G.41 & Control & $920 \pm 25$ & $1,175 \pm 29$ \\
M.26 & Telone-C35 & $923 \pm 58$ & $1,172 \pm 77$ \\
G.41 & Telone-C35 & $852 \pm 30$ & $1,089 \pm 45$ \\
M.26 & SM 2.2 t ha & $935 \pm 33$ & $1,191 \pm 41$ \\
G.41 & SM 2.2 t ha & $910 \pm 52$ & $1,154 \pm 72$ \\
M.26 & SM 4.4 t ha & $861 \pm 56$ & $1,079 \pm 60$ \\
G.41 & SM 4.4 t ha & $828 \pm 42$ & $1,040 \pm 43$ \\
M.26 & SM 6.6 t ha & $840 \pm 81$ & $1,068 \pm 105$ \\
G.41 & SM 6.6 t ha & $768 \pm 63$ & $958 \pm 75$ \\
\hline
\end{tabular}

$x$ An OTU is defined as sequences sharing $>97 \%$ similarity.

y Treatment designations are as follows: control indicates no treatment control, seed meal (SM) indicates Brassica juncea-Sinapis alba, and TeloneC35 indicates 1,3-dichloropropene/chloropicrin fumigation.

${ }^{\mathrm{z}}$ Data are indicated as the mean \pm standard deviation $(n=6)$. 
the tree rows. P. penetrans (Jaffee et al. 1982b) and Pythium spp. (Jaffee et al. 1982a) not only contribute to development of replant disease of apple but may limit growth and yield of established trees (Santo and Wilson 1990). Initial suppression of apple root infection by P. penetrans and Pythium spp. observed in SM-treated soil in this study likely resulted from the generation of AITC, which has activity toward both pathogens. Although preplant soil fumigation with 1,3dichloropropene/chloropicrin controlled $P$. penetrans root infestation during the initial growing season, lesion nematode populations rapidly recovered in fumigated soils during the second orchard growing season, which is consistent with a previous study (Mazzola et al. 2015). In contrast, extended suppression of root lesion nematode root densities was observed for all SM treatments and corresponded with significant differences in the rhizosphere microbiome, including amplification of various nematophagous fungi (e.g., Arthrobotrys spp.), relative to the fumigated and control soils.

The long-term disease suppression obtained in response to Brassicaceae SM amendment in this and previous studies (Mazzola et al. 2015) may be owing to shifts in overall composition of the soil or rhizosphere microbiome (Cohen et al. 2005; Mazzola et al.
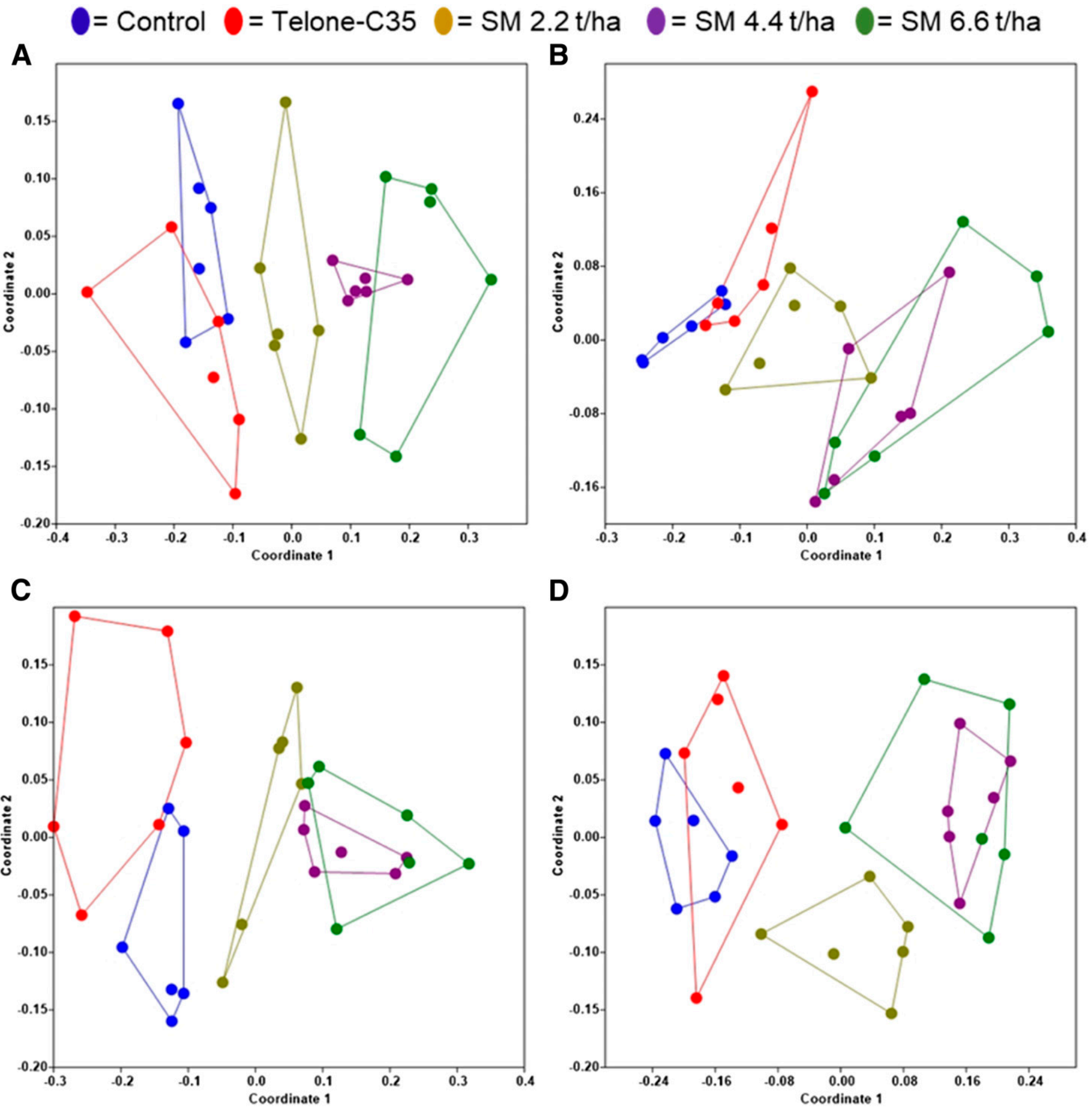

Fig. 5. Effect of soil treatment on composition of the microbiome in the rhizosphere of Gala/G.41 (A, fungi and B, bacteria) and Gala/M.26 (C, fungi and D, bacteria) 1 year postplanting at the Columbia View Research and Demonstration Orchard. Ordination of rhizosphere soil microbiomes was conducted by nonmetric multidimensional scaling of operational taxonomic unit data using the Bray-Curtis dissimilarity coefficient. The convex hulls enclosing all data points for a given treatment are presented. Treatments: Seed meal (SM) indicates Brassica juncea-Sinapis alba, and Telone-C35 indicates 1,3-dichloropropene/chloropicrin preplant soil fumigation. 
2015). The capacity of indigenous soil microbial resources to effectively provide soilborne disease control in agricultural ecosystems has been identified as naturally expressed in several disease-suppressive soils (Raaijmakers and Mazzola 2016). In addition, development of a persistent disease-suppressive orchard soil in response to Brassicaceae SM-induced transformation of the microbial community was documented previously in both greenhouse and field studies (Cohen and Mazzola 2006; Mazzola et al. 2015; Weerakoon et al. 2012). Sustained differences in composition of the soil microbiome were not observed in studies that monitored bulk soil bacterial (Rudolph et al. 2019) or fungal (Wang et al. 2012) community composition after $B$. juncea SM soil amendment. Several experimental disparities likely resulted in the absence of a persistent differentiation in microbial community structure in these SM-treated soils relative to the control. These include the use of SM from a singular plant species, a lower SM application rate, and failure to tarp soil after SM incorporation to enhance retention of resulting volatiles, such as AITC. Previously, a study examining the effect of simulated soil tarping of B. juncea SM-amended soil demonstrated that the fungal community in SM-treated soil that was not tarped was highly similar to the nontreated soil, whereas the community from the tarped SM-treated soil was significantly different (Weerakoon et al. 2012). These relative differences in fungal community composition between the tarped and nontarped SM treatments, including amplification of Trichoderma spp. in tarped soil, corresponded with significant differences in soil suppressiveness to Pythium abapppressorium; tarped SM-treated soil was significantly more suppressive to the pathogen.

In this study, species of rhizosphere fungi and bacteria with a potential role in disease suppression were observed with greater

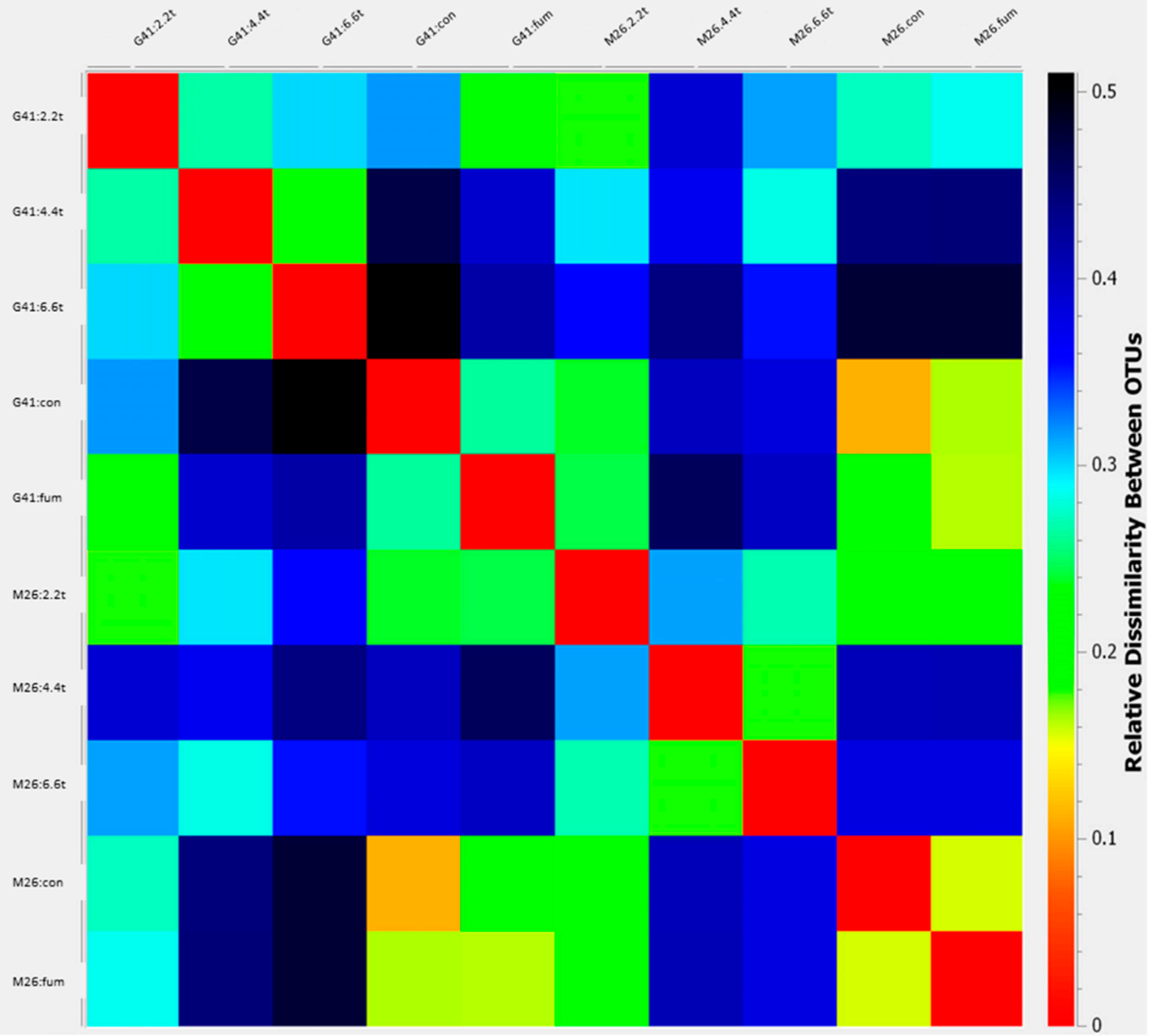

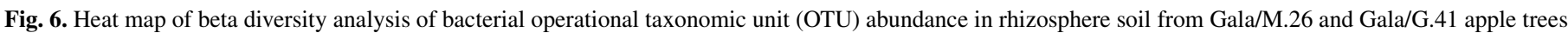

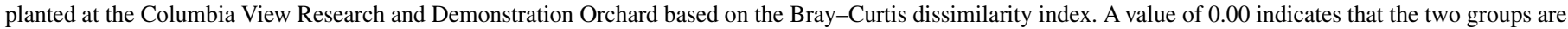

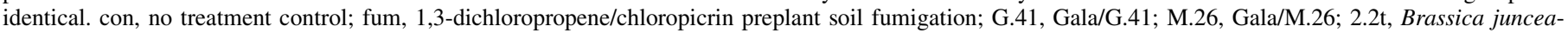

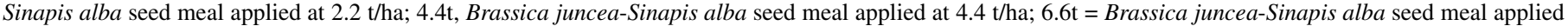
at $6.6 \mathrm{t} / \mathrm{ha}$. 
abundance in SM treatments relative to the control. Several species of fungi reported to possess antifungal activity, such as C. globosum, G. brevispora, Humicola grisea, and Trichoderma spp., were detected at greater abundance in rhizosphere soil from the SMtreated soils than the control soil. C. globosum is a plant endophytic fungus that produces a variety of bioactive metabolites, some of which are reported to induce host resistance to diseases caused by soilborne pathogens (Istifadah and McGee 2006; Zhou et al. 2016). G. brevispora was demonstrated to possess antifungal activity toward numerous fungi (Boonsang et al. 2014). H. grisea is a chitinase-producing strain (Kumar et al. 2017), and Trichoderma spp. are well-known mycoparasites of $R$. solani and Pythium spp. (Chet et al. 1981). Amplification of Trichoderma spp. in response to incorporation of Brassica residues has been reported previously

A

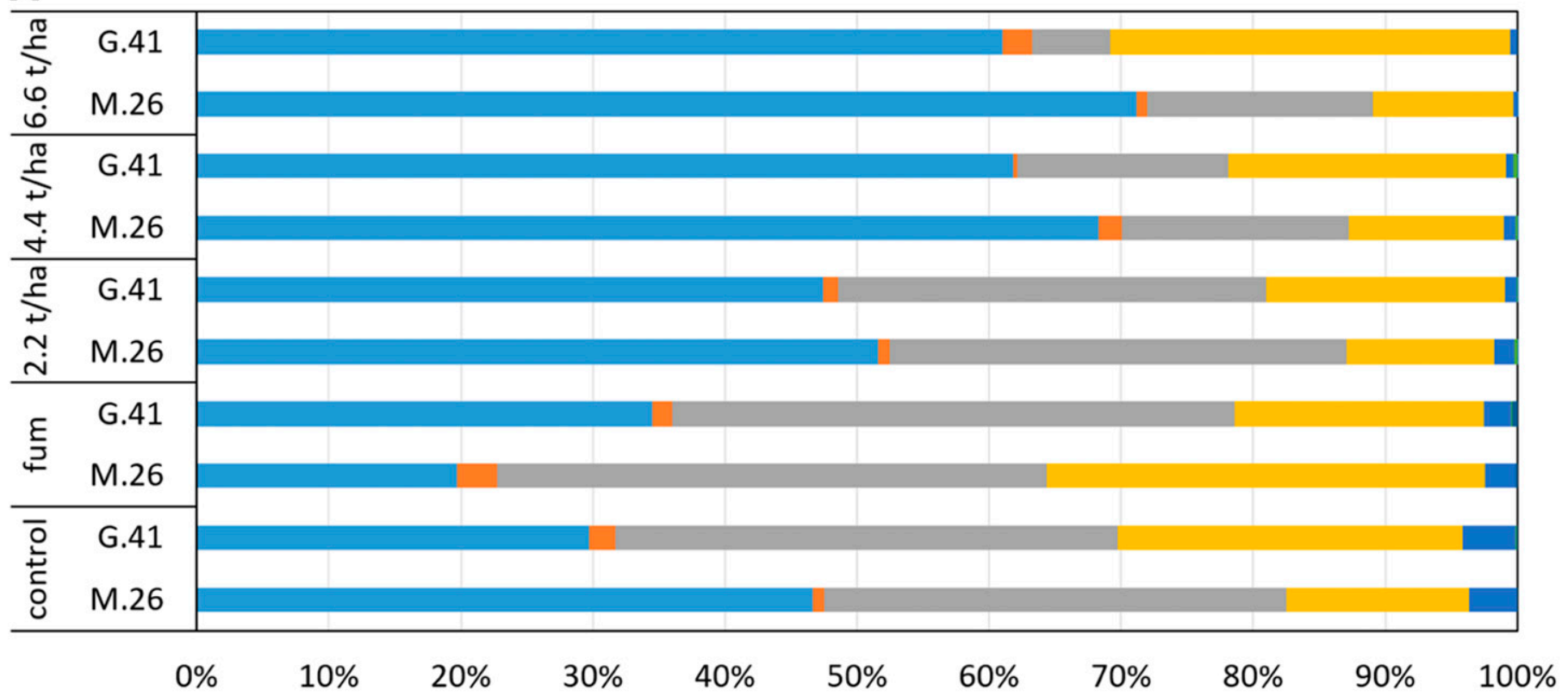

B

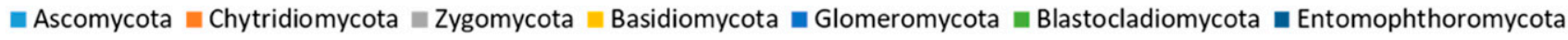

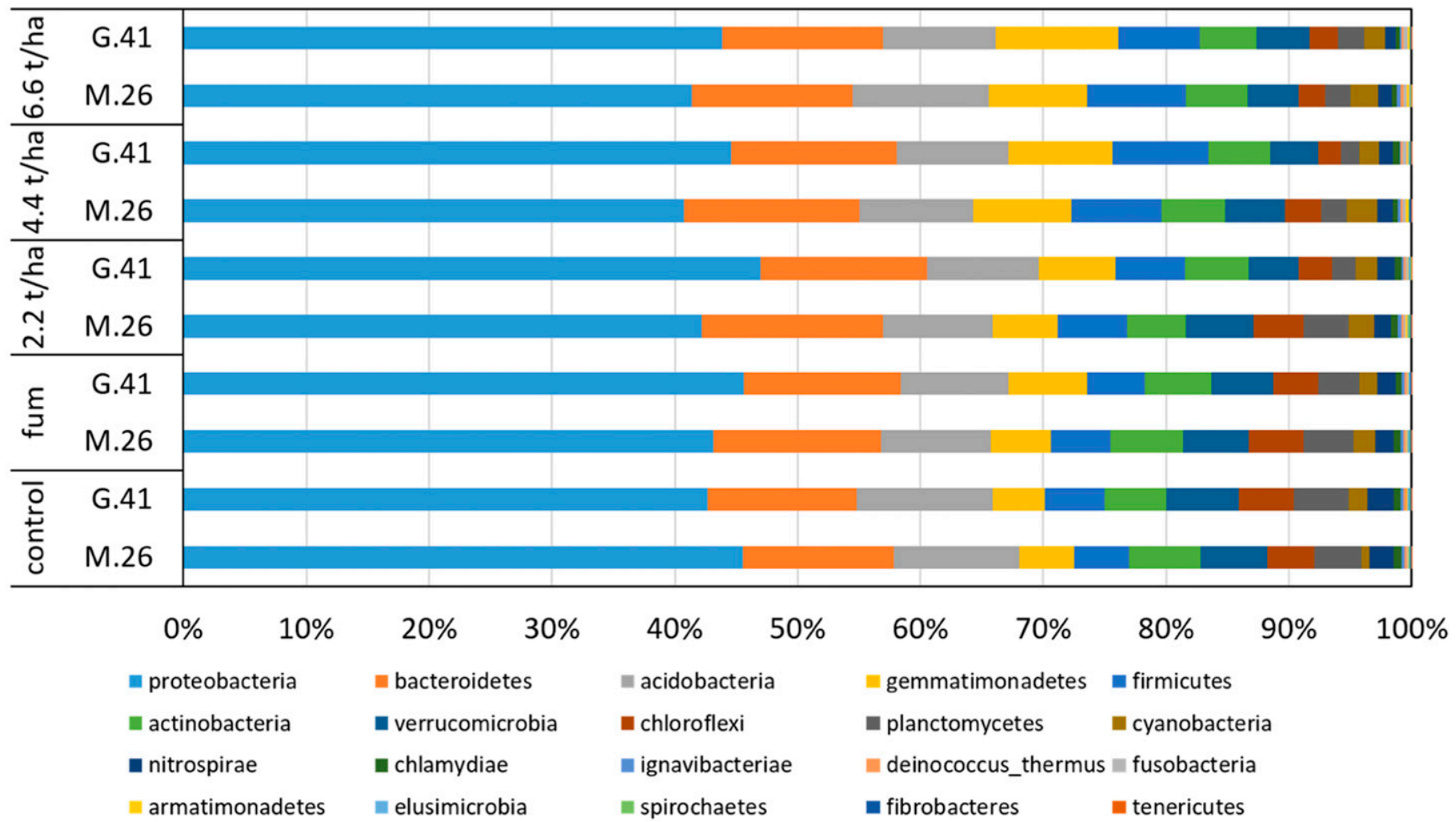

Fig. 7. Proportion of A, fungal and B, bacterial sequences at the phylum level detected in the rhizosphere of Gala/M.26 and Gala/G.41 as influenced by soil treatment at 1 year postplanting in the field trial conducted at the Columbia View Research and Demonstration Orchard. Treatments: control, no treatment control; fum, 1,3-dichloropropene/chloropicrin preplant soil fumigation; G.41, Gala/G.41; M.26, Gala/M.26; 2.2t, Brassica juncea-Sinapis alba seed meal applied at 2.2 t/ha; 4.4t, Brassica juncea-Sinapis alba seed meal applied at $4.4 \mathrm{t} / \mathrm{ha} ; 6.6 \mathrm{t}=$ Brassica juncea-Sinapis alba seed meal applied at $6.6 \mathrm{t} / \mathrm{ha}$. 
(Izzo and Mazzola 2007; Weerakoon et al. 2012), an outcome resulting from its tolerance toward ITCs (Galletti et al. 2008). Additionally, numerous bacterial genera with biological disease control potential, such as the genera Pseudomonas, Streptomyces, and Bacillus, were detected in significantly greater abundance in rhizosphere soil after SM treatment compared with the control treatment. The increased abundance of Streptomyces spp. in Brassicaceae SM-amended soils has been repeatedly documented in studies that have utilized culture-based (Cohen and Mazzola 2006; Cohen et al. 2005; Mazzola et al. 2007) and high-throughput sequencing (Hollister et al. 2013; Mazzola et al. 2015) methods.

Rootstock genotype also played an important role in disease development in this study, because Gala/G.41 possessed significantly lower root densities of $P$. penetrans relative to Gala/M.26 throughout the 2-year study period. Differential tolerance among apple rootstock genotypes to $P$. penetrans has been reported (Isutsa and Merwin 2000) along with a significant rootstock genotype $\times$ SM interaction in nematode suppression (Mazzola et al. 2009). In this multiyear study, P. penetrans root densities were not only higher in Gala/M.26 than Gala/G.41but also, increased more rapidly. Although lesion nematode root densities in Gala/M.26 also increased in SM-amended soil, $P$. penetrans populations remained static over 2 years for Gala/G.41 cultivated in the same SM-treated soils. This finding indicates that the use of the SM soil amendment in concert with a lesion nematode-tolerant apple rootstock may provide extended suppression of $P$. penetrans in orchard production systems.

Contribution of the rhizosphere microbiome to limiting pathogen invasion of roots may vary with plant genotype owing to differences in microbial community structure, which can be mediated by host genetics (Funell-Harris et al. 2010; Micallef et al. 2009). In this study, differences in composition of the rhizosphere and root microbiome from Gala/G.41 cultivated in SM-treated soils were more distinct from the control or fumigation treatment than the corresponding microbiome from Gala/M.26. The selective capacity of plant genotype on the apple rhizosphere microbiome has been reported previously (Fazio and Mazzola 2004; Rumberger et al. 2004; St. Laurent et al. 2010). Sequences of Burkholderia cepacia, which is known to suppress a variety of pathogens (including Pythium spp. and R. solani) (Mazzola 1999), were observed in the root zone of rootstock G.210; however, no sequences representative of that species were obtained from M.26 rootstock (St. Laurent et al. 2010). In this study, rhizosphere bacterial communities were highly similar from Gala/G.41 and Gala/M.26 planted in fumigated or control soils. The same bacterial communities exhibited a decline in relative similarity between the two rootstock genotypes when cultivated in SM-amended soil, suggesting that differences in the host genotype-dependent rhizosphere microbiome composition may be amplified in SM-amended soils.

Interestingly, the relative differences in composition of the rhizosphere microbiome across soil treatments were similarly demonstrated for the Gala/G.41 root microbiome but were not realized for Gala/M.26 trees. The fungal community detected in M.26 roots from the SM 6.6-t ha ${ }^{-1}$ treatment soil was more similar to the control and fumigation treatments. The M.26 rootstock demonstrated sensitivity to the SM amendment at this application rate, and root damage incurred owing to phytotoxicity may have superseded the effect of the SM in shaping the root fungal community. Trees cultivated in the control and fumigated soils likely experienced greater root damage inflicted by root pathogens, including $P$. penetrans. Whether biologically or chemically induced, such root damage is temporally likely to yield a change in exudate availability with a corresponding potential to alter the rhizosphere microbiome (Dudenhöffer et al. 2016; Mazzola and Cook 1991).

Soil amendment- or host genotype-dependent pathogen suppression conferred through activity of the soil microbiome could function as a valuable asset in development of a nonfumigant disease management strategy. The rapid changes in soil microbial community density and composition observed in response to SM application are of significant interest; however, identification of the functional elements that operate in disease control is crucial for the linkage or integration of practices to enhance overall treatment efficacy. Although contribution of the soil microbiome to system resilience is commonly reported as reliant on microbial diversity, the Chao 1 index indicated that diversity within the rhizosphere microbiome decreased with increasing rate of SM application. Mazzola et al. (2015) described a similar negative association between microbiome diversity and development of an orchard soil system that was suppressive to disease and resistant to reinfestation by soilborne plant pathogens. In certain instances, microbiomemediated plant protection may rely more on the presence of species with particular traits than overall diversity of the microbiome (Brussaard et al. 2007; Mazzola et al. 2015).

In summary, three rates of SM amendment evaluated resulted in significantly greater tree growth in this replant orchard trial and effectively controlled soilborne disease and weeds relative to the no treatment control. The amount of disease suppression attained in response to SM treatment exhibited greater persistence relative to that observed in response to preplant soil fumigation. An SM application rate of $4.4 \mathrm{t} \mathrm{ha}^{-1}$ resulted in tree growth performance that was equivalent or superior to that attained at the highest SM application rate $\left(6.6 \mathrm{t} \mathrm{ha}^{-1}\right)$ by the end of the second growing season. In addition, use of the lower SM application rate seemed to circumvent the potential for phytotoxicity that has been observed when utilizing a spring SM application rate of $6.6 \mathrm{t} \mathrm{ha}^{-1}$ during the year of tree planting. The three SM application rates used in this study demonstrated an equivalent capacity to control weeds before planting and suppress the replant disease pathogens $P$. penetrans and Pythium spp. The incidence of P. penetrans root infection was significantly less in roots of apple trees grafted to rootstock G.41 relative to M.26. The differences between rootstocks in terms of root infection by Pythium spp. and P. penetrans became less distinct when cultivated in SM-treated soils. The effect of SM amendment in transforming composition of the rhizosphere microbiome was persistent across two growing seasons, whereas the rhizosphere microbiome in fumigated soil was indistinguishable from the control when examined at 1 year after planting. As observed in a previous study, a decrease in microbial diversity was observed in response to SM treatments; however, microorganisms with particular traits, such as antifungal/antibacterial function, were of greater abundance in SM-treated soil relative to the control 1 year after planting. Rhizosphere soil from the SM application rate of $4.4 \mathrm{t}$ $\mathrm{ha}^{-1}$ possessed a microbiome of similar composition in terms of functionally important microbial elements to that detected in the SM 6.6-t ha $\mathrm{h}^{-1}$ treatment. Overall, integration of the appropriate rootstock genotype with reduced Brassicaceae SM application rates may provide a superior level of apple replant disease control and tree performance relative to conventional soil fumigation. In addition, the treatment may provide long-term benefits to the production system by limiting reinfestation of orchard soils by various soilborne pathogens of apple. Such findings may accelerate the commercial adoption of this technique and ensure economic benefits to growers by reducing orchard establishment costs.

\section{LITERATURE CITED}

Aira, M., Gómez-Brandón, M., Lazcano, C., Bååth, E., and Domínguez, J. 2010. Plant genotype strongly modifies the structure and growth of maize rhizosphere microbial communities. Soil Biol. Biochem. 42:2276-2281.

Auvil, T. D., Schmidt, T. R., Hanrahan, I., Castillo, F., McFerson, J. R., and Fazio, G. 2011. Evaluation of dwarfing rootstocks in Washington apple replant sites. Acta Hortic. 903:265-271.

Bai, Y., Sun, Q., Zhao, C., Wen, D., and Tang, X. 2009. Aerobic degradation of pyridine by a new bacterial strian, Shinella zoogloeoides BC026. J. Ind. Microbiol. Biotechnol. 36:1391-1400.

Blaud, A., Diouf, F., Herrmann, A. M., and Lerch, T. Z. 2015. Analysing the effect of soil organic matter on bacterial communities using T-RFLP fingerprinting: Different methods, different stories? Biol. Fertil. Soils 51:959-971. 
Bodenhausen, N., Bortfeld-Miller, M., Ackermann, M., and Vorholt, J. A. 2014. A synthetic community approach reveals plant genotypes affecting the phyllosphere microbiota. PLoS Genet. 10:e1004283.

Boonsang, N., Dethoup, T., Singburaudom, N., Gomes, N. G. M., and Kijjoa, A. 2014. In vitro antifungal activity screening of crude extracts of soil fungi against plant pathogenic fungi. J. Biopesticides 7:156-166.

Braun, P. G., Fuller, K. D., McRae, K., and Fillmore, S. A. E. 2010. Response of "Honeycrisp" apple trees to combinations of pre-plant fumigation, deep ripping, and hog manure compost incorporation in a soil with replant disease. HortScience 45:1702-1707.

Brussaard, L., de Ruiter, P. C., and Brown, G. G. 2007. Soil biodiversity for agricultural sustainability. Agric. Ecosyst. Environ. 121:233-244.

Castillo-Lopez, D., Zhu-Salzman, K., Ek-Ramos, M. J., and Sword, G. A. 2014. The entomopathogenic fungal endophytes Purpureocillium lilacinum (formerly Paecilomyces lilacinus) and Beauveria bassiana negatively affect cotton aphid reproduction under both greenhouse and field conditions. PLoS One 9:e103891.

Chet, I., Harman, G. E., and Baker, R. 1981. Trichoderma hamatum: Its hyphal interactions with Rhizoctonia solani and Pythium spp. Microb. Ecol. 7:29-38.

Chung, W. C., Huang, J. W., Huang, H. C., and Jen, J. F. 2002. Effect of ground Brassica seed meal on control of Rhizoctonia damping-off of cabbage. Can. J. Plant Pathol. 24:211-218.

Cohen, M. F., and Mazzola, M. 2006. Resident bacteria, nitric oxide emission and particle size modulate the effect of Brassica napus seed meal on disease incited by Rhizoctonia solani and Pythium spp. Plant Soil 286:75-86.

Cohen, M. F., Yamasaki, H., and Mazzola, M. 2005. Brassica napus seed meal soil amendment modifies microbial community structure, nitric oxide production and incidence of Rhizoctonia root rot. Soil Biol. Biochem. 37: 1215-1227.

Covey, R., Benson, N. R., and Haglund, W. A. 1979. Effects of soil fumigation on the apple replant disease in Washington. Phytopathology 69:684-686.

Dudenhöffer, J. H., Scheu, S., and Jousset, A. 2016. Systemic enrichment of antifungal traits in the rhizosphere microbiome after pathogen attack. J. Ecol. 104:1566-1575.

Earlywine, D. T., Smeda, R. J., Teuton, T. C., Sams, C. E., and Xiong, X. 2010. Evaluation of oriental mustard (Brassica juncea) seed meal for weed suppression in Turf. Weed Technol. 24:440-445.

Fazio, G., and Mazzola, M. 2004. Target traits for the development of marker assisted selection of apple rootstocks-prospects and benefits. Acta Hortic. 663:823-828.

Franke-Whittle, I. H., Juárez, M. F. D, Insam, H., Schweizer, S., Naef, A., Topp, A.-R., Kelderer, M., Rühmer, T., Baab, G., Henfrey, J., and Manici, L. M. 2018. Performance evaluation of locally available composts to reduce replant disease in apple orchards of central Europe. Renew. Agr. Food Syst. 2018:1-15

Funnell-Harris, D. L., Pedersen, J. F., and Sattler, S. E. 2010. Soil and root populations of fluorescent Pseudomonas spp. associated with seedlings and field-grown plants are affected by sorghum genotype. Plant Soil. 335: 439-455.

Galletti, S., Sala, E., Leoni, O., Burzi, P. L., and Cerato, C. 2008. Trichoderma spp. tolerance to Brassica carinata seed meal for a combined use in biofumigation. Biol. Control 45:319-327.

Gardner, W., Mulvey, E. P., and Shaw, E. C. 1995. Regression analyses of counts and rates: Poisson, overdispersed Poisson, and Negative Binomial models. Psychol. Bull. 118:392-404.

Hammer, Ø., Harper, D. A. T., and Paul, D. R. 2001. Past: Paleontological statistics software package for education and data analysis. Palaeontol. Electronica 4:1-9.

Handiseni, M., Brown, J., Zemetra, R., and Mazzola, M. 2011. Herbicidal activity of Brassicaceae seed meal on wild oat (Avena fatua), Italian ryegrass (Lolium multiflorum), redroot pigweed (Amaranthus retroflexus), and prickly lettuce (Lactuca serriola). Weed Technol. 25:127-134.

Hanson, B. D., and Shrestha, A. 2006. Weed control with methyl bromide alternatives. CAB Rev. Perspect. Agric. Vet. Sci. Nutr. Nat. Resour. 63:1-13.

Hilyard, E. J., Jones-Meehan, J. M., Spargo, B. J., and Hill, R. T. 2008. Enrichment, isolation, and phylogenetic identification of polycyclic aromatic hydrocarbon-degrading bacteria from Elizabeth River sediments. Appl. Environ. Microbiol. 74:1176-1182.

Hollister, E. B., Hu, P., Wang, A. S., Hons, F. A., and Gentry, T. J. 2013. Differential impacts of Brassicaceous and non-Brassicaceous oilseed meals on soil bacterial and fungal communities. FEMS Microbiol. Ecol. 83: 632-641.

Istifadah, N., and McGee, P. A. 2006. Endophytic Chaetomium globosum reduces development of tan spot in wheat caused by Pyrenophora triticirepentis. Australas. Plant Pathol. 35:411-418.

Isutsa, D. K., and Merwin, I. A. 2000. Malus germplasm varies in resistance or tolerance to apple replant disease in a mixture of New York orchard soils. HortScience 35:262-268.
Izzo, A., and Mazzola, M. 2007. Assessing the utility of a taxonomic microarray for monitoring fungal community development in soils exhibiting suppression of root disease. Phytopathology 97:S50.

Jaffee, B. A., Abawi, G. S., and Mai, W. F. 1982a. Fungi associated with roots of apple seedlings grown in soil from an apple replant site. Plant Dis. 66: 942-944

Jaffee, B. A., Abawi, G. S., and Mai, W. F. 1982b. Role of soil microflora and Pratylenchus penetrans in an apple replant disease. Phytopathology 72: 247-251.

Johnson, N. C., Wilson, G. W. T., Wilson, J. A., Miller, R. M., and Bowker, M. A. 2015. Mycorrhizal phenotypes and the law of the minimum. New Phytol. 205:1473-1484.

Kirkegaard, J. A., Gardiner, P. A., Desmarchelier, J. M., and Angus, J. F. 1993. Biofumigation using Brassica species to control pests and diseases in horticulture and agriculture. Pages 77-82 in: Proceedings of the 9th Australian Research Assembly on Brassicas. N. Wratten and R. J. Mailer, eds. Agricultural Research institute, Wagga Wagga, Australia.

Kumar, M., Brar, A., Vivekanand, V., and Pareek, N. 2017. Production of chitinase from thermophilic Humicola grisea and its application in production of bioactive chitooligosaccharides. Int. J. Biol. Macromol. 104: 1641-1647.

Kuyukina, M. S., and Ivshina, I. B. 2010. Rhodococcus biosurfactants: Biosynthesis, properties, and potential applications. Pages 291-313 in: Biology of Rhodococcus. H. Alvarez, ed. Springer, Berlin.

Larkin, R. P., and Griffin, T. S. 2007. Control of soilborne potato diseases using Brassica green manures. Crop Prot. 26:1067-1077.

Larkin, R. P., and Honeycutt, C. W. 2006. Effects of different 3-year cropping systems on soil microbial communities and Rhizoctonia diseases of potato. Phytopathology 96:68-79.

Lee, T. K., Lee, J., Sul, W. J., Iwai, S., Chai, B., Tiedje, J. M., and Park, J. 2011. Novel biphenyl-oxidizing bacteria and dioxygenase genes from a Korean tidal mudflat. Appl. Environ. Microbiol. 77:3888-3891.

Mai, W. F., and Abawi, G. S. 1981. Controlling replant diseases of pome and stone fruits in northeastern United States by preplant fumigation. Plant Dis. 65:859-864.

Mapperson, R. R., Kotiw, M., Davis, R. A., and Dearnaley, J. D. W. 2014. The diversity and antimicrobial activity of Preussia sp., endophytes isolated from Australian dry rainforests. Curr. Microbiol. 68:30-37.

Mazzola, M. 1998. Elucidation of the microbial complex having a causal role in the development of apple replant disease in Washington. Phytopathology 88:930-938.

Mazzola, M. 1999. Transformation of soil microbial community structure and Rhizoctonia-suppressive potential in response to apple roots. Phytopathology 89:920-927.

Mazzola, M., Andrews, P. K., Reganold, J. P., and Lévesque, C. A. 2002. Frequency, virulence, and metalaxyl sensitivity of Pythium spp. isolated from apple roots under conventional and organic production systems. Plant Dis. 86:669-675.

Mazzola, M., and Brown, J. 2010. Efficacy of Brassicaceous seed meal formulations for the control of apple replant disease in conventional and organic production systems. Plant Dis. 94:835-842.

Mazzola, M., Brown, J., Izzo, A. D., and Cohen, M. F. 2007. Mechanism of action and efficacy of seed meal-induced pathogen suppression differ in a Brassicaceae species and time-dependent manner. Phytopathology 97: 454-460.

Mazzola, M., Brown, J., Zhao, X., Izzo, A. D., and Fazio, G. 2009. Interaction of brassicaceous seed meal and apple rootstock on recovery of Pythium spp. and Pratylenchus penetrans from roots grown in replant soils. Plant Dis. 93: 51-57.

Mazzola, M., and Cook, R. J. 1991. Effects of fungal root pathogens on the population dynamics of biocontrol strains of fluorescent pseudomonads in the wheat rhizosphere. Appl. Environ. Microbiol. 57:2171-2178.

Mazzola, M., Granatstein, D. M., Elfving, D. C., and Mullinix, K. 2001. Suppression of specific apple root pathogens by Brassica napus seed meal amendment regardless of glucosinolate content. Phytopathology 91: 673-679.

Mazzola, M., Hewavitharana, S., and Strauss, S. L. 2015. Brassica seed meal soil amendments transform the rhizosphere microbiome and improve apple production through resistance to pathogen reinfestation. Phytopathology 105:460-469.

Mazzola, M., and Manici, L. M. 2012. Apple replant disease: Role of microbial ecology in cause and control. Annu. Rev. Phytopathol. 50:45-65.

Mazzola, M., and Mullinix, K. 2005. Comparative field efficacy of management strategies containing Brassica napus seed meal or green manure for the control of apple replant disease. Plant Dis. 89:1207-1213.

Mazzola, M., and Zhao, X. 2010. Brassica juncea seed meal particle size influences chemistry but not soil biology-based suppression of individual agents inciting apple replant disease. Plant Soil 337:313-324. 
Meyer, S. L. F., Zasada, I. A., Orisajo, S. B., and Morra, M. J. 2011. Mustard seed meal mixtures: Management of Meloidogyne incognita on pepper and potential phytotoxicity. J. Nematol. 43:7-15.

Meyer, S. L. F., Zasada, I. A., Rupprecht, S. M., VanGessel, M. J., Hooks, C. R. R., Morra, M. J., and Everts, K. L. 2015. Mustard seed meal for management of root-knot nematode and weeds in tomato production. HortTechnology 25:192-202.

Micallef, S. A., Channer, S., Shiaris, M. P., and Colon-Carmona, A. 2009. Plant age and genotype impact progression of bacterial community succession in the Arabidopsis rhizosphere. Plant Signal. Behav. 4:777-780.

Raaijmakers, J. M., and Mazzola, M. 2016. Soil immune responses. Science 352:1392-1393.

Reardon, C. L., Strauss, S. L., and Mazzola, M. 2013. Changes in available nitrogen and nematode abundance in response to Brassica seed meal amendment of orchard soil. Soil Biol. Biochem. 57:22-29.

Robertson, C. E., Harris, J. K., Wagner, B. D., Granger, D., Browne, K., Tatem, B., Feazel, L. M., Park, K., Pace, N. R., and Frank, D. N. 2013. Explicet: Graphical user interface software for metadata-driven management, analysis and visualization of microbiome data. Bioinformatics 29:3100-3101.

Robinson, T., Fazio, G., Aldwinckle, H. 2014. Characteristics and performance of four new apple rootstock from the Cornell-USDA apple rootstock breeding program. Acta Hort. 1058:651-656.

Rothlisberger, K. L., Hons, F. M., Gentry, T. J., and Senseman, S. A. 2012. Oilseed meal effects on emergence and survival of crop and weed species. Appl. Environ. Soil Sci. 2012:1-10.

Rudolph, R. E., Zasada, I. A., Hesse, C., and DeVetter, L. W. 2019. Brassicaceous seed meal, root removal and chemical fumigation vary in their effects on soil quality parameters and Pratylenchus penetrans in a replanted floricane raspberry production system. Appl. Soil Ecol. 133:44-51.

Rumberger, A., Yao, S., Merwin, I. A., Nelson, E. B., and Thies, J. E. 2004. Rootstock genotype and orchard replant position rather than soil fumigation or compost amendment determine tree growth and rhizosphere bacterial community composition in an apple replant soil. Plant Soil 264:247-260.

Santo, G. S., and Wilson, J. H. 1990. Effects of fenamiphos on Pratylenchus penetrans and growth of apple. J. Nematol. 22:779-782.

Shipton, P. J. 1977. Monoculture and soil-borne plant pathogens. Annu. Rev. Phytopathol. 15:387-407.

Slykhuis, J. T., and Li, T. S. C. 1985. Responses of apple seedlings to biocides and phosphate fertilizers in orchard soils in British Columbia. Can. J. Plant Pathol. 7:294-301

St. Laurent, A., Merwin, I. A., Fazio, G., Thies, J. E., and Brown, M. G. 2010. Rootstock genotype succession influenced apple replant disease and root-zone microbial community composition in an orchard soil. Plant Soil 337:259-272.

Supaphon, P., Phongpaichit, S., Rukachaisirikul, V., and Sakayaroj, J. 2013. Antimicrobial potential of endophytic fungi derived from three seagrass species: Cymodocea serrulate, Halophila ovalis and Thalassia hemprichii. PLoS One 8:e72520.

Tewoldemedhin, Y. Y., Mazzola, M., Botha, W. J., Spies, C. F. J., and McLeod, A. 2011. Characterization of fungi (Fusarium and Rhizoctonia) and oomycetes (Phytophthora and Pythium) associated with apple orchards in South Africa. Eur. J. Plant Pathol. 130:215-229.

Traquair, J. A. 1984. Etiology and control of orchard replant problems: A review. Can. J. Plant Pathol. 6:54-62.

Wagner, B. D., Roberson, C. E., and Harris, J. K. 2011. Application of twopart statistic for comparison of sequence variant counts. PLoS One 6: e20296.

Wang, A. S., Hu, P., Hollister, E. B., Rothlisberger, K. L., Somenahally, A., Provin, T. L., Hons, F. M., and Gentry, T. J. 2012. Impact of Indian mustard (Brassica juncea) and flax (Linum usitatissimum) seed meal applications on soil carbon, nitrogen, and microbial dynamics. Appl. Environ. Soil Sci. 2012:1-14

Wang, L., and Mazzola, M. 2019a. Effect of soil physical conditions on emission of allyl isothiocyanate and subsequent microbial inhibition in response to brassicaceae seed meal amendment. Plant Dis. 103:846-852.

Wang, L., and Mazzola, M. 2019b. Interaction of Brassicaceae seed meal soil amendment and apple rootstock genotype on microbiome structure and replant disease suppression. Phytopathology 109:607-614.

Weerakoon, M. D., Reardon, L. C., Paulitz, T. C., Izzo, A. D., and Mazzola, M. 2012. Long-term suppression of Pythium abappressorium induced by Brassica juncea seed meal amendment is biologically mediated. Soil Biol. Biochem. 51:44-52.

White, D. C., Sutton, S. D., and Ringelberg, D. B. 1996. The genus Sphingomonas: Physiology and ecology. Curr. Opin. Biotechnol. 7: 301-306.

Yu, Q., Tsao, R., Chiba, M., and Potter, J. 2005. Selective nematicidal activity of allyl isothiocyanate. J. Food Agric. Environ. 3:218-221.

Zhou, W., Starr, J. L., Krumm, J. L., and Sword, G. A. 2016. The fungal endophyte Chaetomium globosum negatively affects both above- and belowground herbivores in cotton. FEMS Microb. Ecol. 92:fiw158.

Zhu, Y., Fazio, G., and Mazzola, M. 2014. Elucidating the molecular responses of apple rootstock resistant to ARD pathogens: Challenges and opportunities for development of genomics-assisted breeding tools. Hortic. Res. 43:1-8. 